\title{
Spatial distributions and seasonal cycles of aerosols in India and China seen in global climate-aerosol model
}

\author{
S. V. Henriksson ${ }^{1}$, A. Laaksonen ${ }^{1,2}$, V.-M. Kerminen ${ }^{1}$, P. Räisänen ${ }^{1}$, H. Järvinen ${ }^{1}$, A.-M. Sundström ${ }^{3}$, and \\ G. de Leeuw ${ }^{1,3}$ \\ ${ }^{1}$ Finnish Meteorological Institute, Helsinki, Finland \\ ${ }^{2}$ Department of Applied Physics, University of Kuopio, Kuopio, Finland \\ ${ }^{3}$ Department of Physics, University of Helsinki, Helsinki, Finland
}

Received: 22 December 2010 - Published in Atmos. Chem. Phys. Discuss.: 3 February 2011

Revised: 30 June 2011 - Accepted: 25 July 2011 - Published: 5 August 2011

\begin{abstract}
A climate-aerosol model is employed to study spatial and temporal variability of aerosol properties over India and China for recent (year 2006) and future conditions (year 2020) under different emission pathways. We present results for aerosol mass concentration in different size classes and optical properties for the five different aerosol species treated by the model. Aerosol mass concentration and optical depth have significant contributions from both anthropogenic and natural aerosols. Different species have maxima in different regions, with the highest anthropogenic aerosol concentrations found in Kolkata and elsewhere in the Ganges basin in India and on the northern part of the east coast and in the Sichuan basin in China. In India, natural aerosols have a maximum in the summer due to higher wind speeds, whereas anthropogenic aerosols have a maximum in the winter due to less efficient wet removal. Surface concentrations also tend to be higher in winter due to the additional reason of lower average boundary layer height. In China, seasonal cycles are weaker with natural aerosols having a maximum in the spring and sulfate contribution to the aerosol optical depth (AOD) being higher in the latter half of the year. MODIS AOD spatial distributions are reproduced well by the model, except for the Ganges valley with high absorption and for the Thar desert with high dust concentrations. Seasonal cycles compare qualitatively well with MODIS measurements.
\end{abstract}

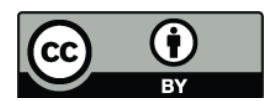

Correspondence to: S. V. Henriksson (svante.henriksson@fmi.fi)

\section{Introduction}

\subsection{Background}

Asia is presently experiencing a high load of aerosols, much of which is of anthropogenic origin. Aerosols have significant effects on human health, the environment and the climate and addressing air quality and climate effects of aerosols simultaneously has become popular in recent years (Ramanathan, 2003; Ramanathan et al., 2007). To quote some numbers from recent studies, outdoor exposure to air pollution is estimated to cause 337000 premature deaths per year in China and India, and exposure to indoor pollution attributable to solid fuel use is estimated to cause an additional 380700 deaths in China and 407100 deaths in India (Ramanathan et al., 2008). Aerosols reduce sunlight coming to the surface in India and China by more than $10 \mathrm{~W} \mathrm{~m}^{-2}$ in most parts of India and China (Ramanathan et al., 2008). Absorbing aerosols heat the atmosphere at elevated levels and increase the absorption of solar radiation when deposited on the glacier surfaces, contributing to glacier melting (Ramanathan et al., 2008), which threatens the water supply and thereby the food security of people living along the rivers receiving melt water flow from the glaciers (Kehrwald et al., 2008). Atmospheric heating caused by absorbing aerosols and surface dimming caused by all aerosols also slow down the hydrological cycle (Chung and Ramanathan, 2006; Xu, 2001). Knowledge of aerosol distributions at large scale is necessary to evaluate their effects on human health, the environment and the climate.

Aerosols over Asia have been studied in several field campaigns, among others INDOEX (Ramanathan et al., 2001), Ace-Asia (Seinfeld et al., 2004) and TRACE-P (Jacob et al.,

Published by Copernicus Publications on behalf of the European Geosciences Union. 
2004). Data from several measurement stations are available, including stations with long-term high-quality data (Carrico et al., 2003; Ramanathan et al., 2007). Finnish Meteorological Institute (FMI) has performed continuous aerosol measurements at two locations in Northern India: Gual Pahari near New Delhi and the remote Mukteshvar, together with The Energy and Resources Institute of India (TERI) (Hyvärinen et al., 2009; Komppula et al., 2009; Hyvärinen et al., 2010). University of Helsinki has made urban measurements in India (Mönkkönen et al., 2004, 2005) and Leibniz Institute for Tropospheric Research has made measurements both in India and China (Franke et al., 2003; Müller et al., 2006). There are several studies on aerosol optical properties seen from satellites and AERONET measurement stations (Ramachandran, 2007; Ramachandran and Cherian, 2008). In recent modeling studies, for instance seasonal cycle characterization and climate impact assessment has been made and satellite measurements of aerosol optical depth have been assimilated with chemical transport models (Adhikary et al., 2007; Roeckner et al., 2006b; Adhikary et al., 2008).

\subsection{Scope of current study}

In this study, we use a global aerosol-climate model to investigate the spatial and temporal variability of aerosol properties over India and China, two regions with high aerosol load but somewhat different emission and climate characteristics. Our goal is to provide information about aerosols at large scale, that may be used for air quality and climate research and assessment purposes. We consider both the present-day situation as well as conditions in the future (year 2020) under different emission pathways. The model used is ECHAM5HAM developed at the Max Planck Institute for Meteorology (MPI-M) (Stier et al., 2005).

We present results for surface aerosol concentrations in the form of $\mathrm{PM}_{1.0}, \mathrm{PM}_{2.5}$ and $\mathrm{PM}_{10}$ and the contributions to these of the chemical components treated by our model: sulfate (SU), black carbon (BC), organic carbon (OC), mineral dust (DU) and sea salt (SS). We will also study optical properties: aerosol optical depth (AOD), absorption aerosol optical depth and Angstrom parameter. AOD will be split up according to the chemical components. In addition to a simulation of present-day Asia (year 2006), we present results for a simulation without any anthropogenic emissions and for simulations with two future scenarios for the year 2020: the reference scenario created by the authors of the Regional Asian Emission Inventory (Ohara, 2007; GEIA/ACCENT 2008) and a scenario with anthropogenic emissions of all aerosol species decreasing by 2 per cent a year. We compare modeled AODs to measurement results from MODIS Terra and AERONET. We also make qualitative comparisons to some other measurements and compare our results with other modeling studies.
We aim to present a wide-perspective look at these aerosol properties, which affect and depend on human life and activities, weather and climate on an essentially regional scale. Local effects are naturally outside the scope of this study. While we are presenting new scientific results we also hope to highlight and clarify some features that are harder to see in more detailed studies. We use a well-established model, a recent emission inventory and scenarios based on the most upto-date information available on the fast-changing socioeconomic situation in these countries. Earlier large-scale model investigations were presented by Adhikary et al. (2007) and Carmichael et al. (2009). The current study uses a detailed aerosol model and considers seasonal cycles as well. Our model also accounts for the effect of aerosols on meteorological conditions.

The model and the simulations are presented in Sect. 2. The Regional Asian Emission Inventory and the emission scenarios used are presented in Sect. 3. Results for presentday Asia are presented in Sect. 4 and for the future simulations in Sect. 5. The main findings are summarized in Sect. 6.

\section{The model and simulations}

The ECHAM5-HAM model is an atmospheric general circulation model (GCM) coupled with an aerosol model. It predicts the evolution of an ensemble of microphysically interacting internally- and externally-mixed aerosol populations as well as their size-distribution and composition. ECHAM5-HAM is described by Stier et al. (2005) and the atmospheric part ECHAM5 by Roeckner et al. (2003, 2006a). The model treats five aerosol species: sulfate, black carbon, organic carbon, mineral dust and sea salt. The first three mentioned components are emitted by both anthropogenic and natural sources and the last two by wind-induced formation from natural sources only. The size-distribution is represented by a superposition of seven log-normal modes (Vignati et al., 2004). Emissions of all species except sulfur compounds are in the form of particulate matter. Except for marine DMS emissions, $97.5 \%$ of sulfur emissions are in the form of $\mathrm{SO}_{2}$ and $2.5 \%$ in the form of primary sulfate. All emissions are distributed evenly inside the model grid box. The aerosol effects on radiation are only considered for the shortwave part of the spectrum. The atmospheric part is a fifth-generation climate model that has evolved from the model of the European Centre for Medium-Range Weather Forecasts (ECMWF).

Sulfur chemistry is based on the sulfur cycle model described in Feichter et al. (1996). The monthly-mean oxidant fields of $\mathrm{OH}, \mathrm{H}_{2} \mathrm{O}_{2}, \mathrm{NO}_{2}$ and $\mathrm{O}_{3}$ are prescribed based on calculations of the MOZART chemical transport model (Horowitz et al., 2003). Gas-phase dimethyl sulfide (DMS) and $\mathrm{SO}_{2}$ are oxidised by the hydroxyl radical, in addition to which DMS reacts with the nitrate radical. In the liquid phase $\mathrm{SO}_{2}$ is oxidised to sulphate by $\mathrm{H}_{2} \mathrm{O}_{2}$ and $\mathrm{O}_{3}$. Sulfate 
produced in the gas phase is allowed to condense onto preexisting particles or to nucleate, whereas in-cloud produced sulfate is distributed between the accumulation and coarse modes (mode radii $r>0.05 \mu \mathrm{m}$ ).

Natural emissions of dust, sea salt and ocean DMS are calculated online and others prescribed. The sea salt emission flux is parametrised utilising the $10 \mathrm{~m}$ wind speed following Schulz et al. (2004). Mineral dust emissions are calculated utilising the $10 \mathrm{~m}$ wind speed and the hydrological parameters following Tegen et al. (2002). DMS emissions from the marine biosphere are calculated using the DMS seawater concentrations of Kettle and Andreae (2000) and utilising the model $10 \mathrm{~m}$ wind speed to derive the air-sea exchange rate (Nightingale et al., 2000). Terrestial biogenic DMS emissions are prescribed according to Pham et al. (1995). $\mathrm{SO}_{2}$, emissions from volcanoes are prescribed following Andres and Kasgnoc (1998) and Halmer et al. (2002). $\mathrm{SO}_{2}$, $\mathrm{BC}$ and $\mathrm{OC}$ emissions from wildfires are based on van der Werf (2003) and biogenic POM emissions on Guenther et al. (1995).

Stier et al. (2005) reported that the model generally agrees well with observations of the global aerosol system. For example, the global annual mean AOD of 0.14 is in excellent agreement with AERONET measurements (0.14) and a composite of MODIS-MISR satellite retrievals (0.16). The model is also able to reproduce the main regional features, although non-negligible deviations exist. In Sect. 4 of this article, some new comparisons between simulation results and observations are provided.

In this study we present results from four simulations with different aerosol emissions, two for the year 2006 and two for the year 2020. The model is run at T42L19 resolution, meaning a horizontal grid spacing of $\sim 2.8$ degrees and 19 vertical levels in a hybrid sigma/pressure coordinate system with the top level at $10 \mathrm{hPa}$. For greenhouse gas concentrations we use the IPCC SRES scenario A1B (Nakicenovic et al., 2000). The sea-surface temperatures and sea ice fields are taken from a simulation with the coupled ECHAM5-MPIOM (Max Planck Institute Ocean Model) atmosphere-ocean GCM (Marsland et al., 2003). All simulations are five-year simulations.

\section{Emission inventory and scenarios}

The REAS emission inventory includes inventories for anthropogenic emissions for $\mathrm{SO}_{2}$, black carbon and organic carbon treated by our model and additionally for $\mathrm{NO}_{\mathrm{x}}$, $\mathrm{CO}$ and NMVOC (nonmethane volatile organic compounds) from fuel combustion and industrial sources. REAS has been produced with a methodology using emission factors, activity data and removal efficiency of emission controls. Emissions are given for 1980-2003 and for three future scenarios for 2010 and 2020: a reference scenario (REF), a policy success case (PSC) and a policy failure case (PFC). Emis- sions for 2004-2009 are available as prediction inventories obtained by linear interpolation of emissions in 2003 and 2010 (PFC scenario). REAS is the first inventory presenting historic, present and future emissions of multiple aerosol species in Asia on the basis of a constant methodology. Another widely used inventory for Asia is that by Streets et al. (2003). See Ohara et al. (2007) for a review on other inventories. Since the REAS inventory, inventories INTEX-B (Zhang et al., 2009) and GAINS-Asia (Klimont et al., 2009) have been published.

Seasonal variations in anthropogenic emissions are not considered in the REAS inventory. Thus, for example emissions due to increased heating in colder regions during winter or emissions due to increased tourism in the summer are omitted. In spite of this limitation, the seasonal variations in aerosol properties in our simulations seem quite reasonable (Sect. 4.1). Variations within the year shown in the following plots are caused by meteorological conditions influencing aerosol processes and variations in natural aerosol emissions. Some emission inventories have taken seasonal variations of emissions into account, though their estimation is not an easy task. Streets et al. (2003) estimated seasonal variations of residential emissions in Asia assuming a provincial monthly mean temperature dependence of stove usage. Zhang et al. (2009) used the same methodology to estimate the seasonal variations of residential emissions and available statistics to estimate seasonal variations of emissions from industy and power generation in China. Emissions were estimated to be lower in the summer with maximum ratios between maxima and minima in monthly values of 2.1, 2.8 and 1.4 for $\mathrm{BC}, \mathrm{OC}$ and $\mathrm{SO}_{2}$ emissions, respectively. In most of India we expect less seasonal variations in residential emissions, because of the country being closer to the equator and monthly mean temperatures therefore generally varying less than in China. However, the unaccounted emission seasonality will inevitably cause some error to the results and it is clear that, if the seasonality would be taken into account and total emissions would stay the same, then $\mathrm{SO}_{2}, \mathrm{BC}$ and $\mathrm{OC}$ concentrations would increase in the winter and decrease in the summer.

Anthropogenic emissions of $\mathrm{SO}_{2}$, black carbon and organic carbon are overall very large for China and India both in the REAS inventory and the future scenarios. In the year 2000, $\mathrm{SO}_{2}$ emissions were 27.6 Mt for China and $6.1 \mathrm{Mt}$ for India. BC emissions were $1.1 \mathrm{Mt}$ for China and $0.8 \mathrm{Mt}$ for India while organic carbon emissions were $2.6 \mathrm{Mt}$ for China and 3.3 Mt for India. Emissions from open burning of biomass are not included in the REAS inventory. Venkataraman et al. (2006) estimated open burning of forest and crop waste to contribute about $25 \%$ to $\mathrm{BC}$ and $\mathrm{OC}$ emissions in India, and negligibly to $\mathrm{SO}_{2}$ emissions. The omission of open biomass burning emissions will cause some error in our simulations, particularly during the peak forest burning periods occuring in February to May and harvesting seasons with most crop waste burning, with peaks in April and October. 
However, the omitted numbers fall well within the large uncertainty in BC and OC emissions (Streets et al., 2003; Ohara et al., 2007).

The main source for the strikingly high $\mathrm{SO}_{2}$ emissions in China is coal combustion in power plants and industrial facilities, most of which lacked desulfurization systems, something that has improved since the REAS inventory was made (Lu et al., 2010). In India coal combustion in power plants and oil combustion in industry gave major contributions to the total $\mathrm{SO}_{2}$ emissions. Taking Japan as a reference, the mean emission factor for $\mathrm{SO}_{2}$ emissions from coal combustion in power plants in 2000 was $833.6 \mathrm{~g} \mathrm{GJ}^{-1}$ in China and $550.9 \mathrm{~g} \mathrm{GJ}^{-1}$ in India compared to $26.2 \mathrm{~g} \mathrm{GJ}^{-1}$ in Japan. Emission factors from industry were $934.2 \mathrm{~g} \mathrm{GJ}^{-1}$ for China and $250.1 \mathrm{~g} \mathrm{GJ}^{-1}$ for Japan. The mean emission factor for $\mathrm{SO}_{2}$ emissions from oil combustion in industry was $148.7 \mathrm{~g} \mathrm{GJ}^{-1}$ in China and $562.1 \mathrm{~g} \mathrm{GJ}^{-1}$ in India compared to $35.9 \mathrm{~g} \mathrm{GJ}^{-1}$ in Japan.

The major source for the very large $\mathrm{BC}$ and $\mathrm{OC}$ emissions was domestic fuel combustion for both countries, where in China both biomass and coal accounted for large shares and in India biomass burning was dominant. Domestic fuel combustion when cooking with fuels such as wood, crop residues, dung and coal is often done in stoves with very incomplete combustion and poor ventilation with the airborne pollution released to the living area and the atmosphere. Also fuel efficiency is often very low. Even stoves using wood, which is one of the cleaner biofuels, typically produce carbon monoxide and hydrocarbon emissions 50 times higher compared to cooking an equivalent meal on a gas stove, as an example (Bruce et al., 2002). In urban areas, traffic is also a heavy emitter, especially of the $\mathrm{NO}_{\mathrm{x}}$ compounds not treated by our model.

Large emissions imply that there is a lot of potential for reductions. Most $\mathrm{SO}_{2}$ emissions could be eliminated by introducing desulfurizations systems. The above comparison of emission factors with Japan indicates that remarkable emission reductions can be made even in the current fossil fuel based facilities. Furthermore, in India and China there is enormous potential for renewable energy such as wind and solar power, which help to curb both the air quality and climate effects of electricity production. Household emissions of BC and OC could be reduced by replacing solid fuels with cleaner energy sources (e.g. Project Surya, Edwards et al., 2007) and by using stoves of improved design (Ramanathan et al., 2009; Hanbar and Karve, 2002).

In view of international treaties on climate and air quality, the emissions will likely be reduced, following e.g. China's outspoken goal on sulfate emission reductions (Xin and Stone, 2008). To study effects of emission reductions, we developed for this study a scenario with anthropogenic emissions of sulfur, BC and OC all decreasing by 2 per cent per year in Asia throughout. We call this scenario the $-2 \%$ per year scenario. A lot faster emission reductions are also possible. Effects of large emission cuts are already con-

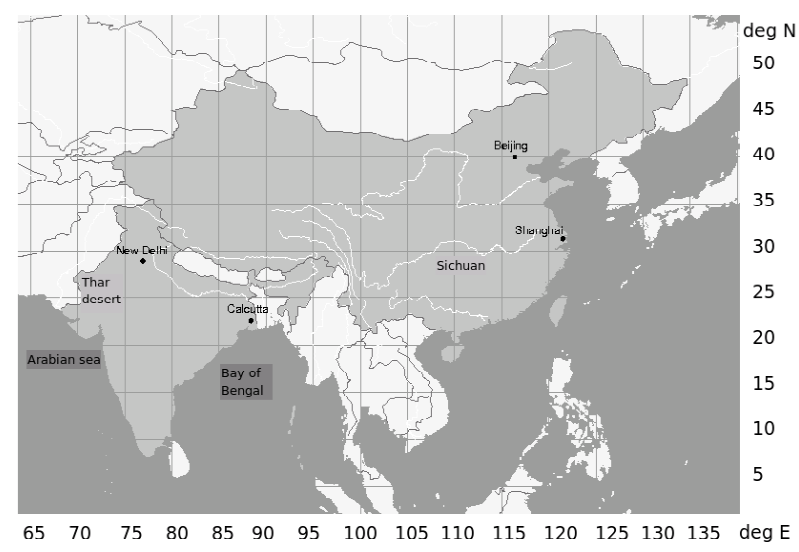

Fig. 1. Map of South and East Asia including India and China. Results presented for India are averages over the area $5-35^{\circ} \mathrm{N} \times$ $65-90^{\circ} \mathrm{E}$ and results for China are averages over the areas $20-45^{\circ} \mathrm{N}$ $\times 95-125^{\circ} \mathrm{E}$ and $35-45^{\circ} \mathrm{N} \times 75-95^{\circ} \mathrm{E}$.

sidered in some studies (e.g. in Jacob et al., 2004 and Ramanathan and Carmichael, 2008).

We present results from four different simulations: simulations of the years 2005-2009 with (1) REAS prediction inventory emissions for the year 2006 and (2) completely without anthropogenic emissions; and simulations of the years 2019-2023 with (3) the REAS REF scenario and with (4) the $-2 \%$ per year scenario. Anthropogenic emissions outside Asia are set to zero, which causes some negative bias to aerosol concentrations. However, this bias is likely to be very small as anthropogenic emissions are still treated for a much larger region than the one analysed (Ohara et al., 2007). The first year of each simulation is used as spin-up and results are presented for the remaining four years.

\section{Aerosol characteristics in present-day India and China}

In the following we present characteristics of aerosol concentrations and optical properties in present-day Asia. The domain-mean results we report for India are averages over the longitude-latitude box stretching from $5^{\circ} \mathrm{N}$ to $35^{\circ} \mathrm{N}$ and from $65^{\circ} \mathrm{E}$ to $90^{\circ} \mathrm{E}$. The results for China are averages over the two longitude-latitude boxes $20-45^{\circ} \mathrm{N} \times 95-125^{\circ} \mathrm{E}$ and $35-45^{\circ} \mathrm{N} \times 75-95^{\circ}$ E. Figure 1 shows a map of the region. For plotting convenience the Chinese spatial distributions are shown only from $95^{\circ} \mathrm{E}$ eastward.

We present results for mass concentration in different size classesPM $\mathrm{P}_{1.0}, \mathrm{PM}_{2.5}$ and $\mathrm{PM}_{10.0}$ (Figs. 2, 4, 8 and 9) and the optical properties: AOD (Figs. 3, 5 and 10), absorption AOD (Abs) and Angstrom parameter (Ang) (Fig. 11). All AOD values presented here are values at $\lambda=550 \mathrm{~nm}$. We split up the concentrations in different size classes and AOD to the five different aerosol species involved. As only 


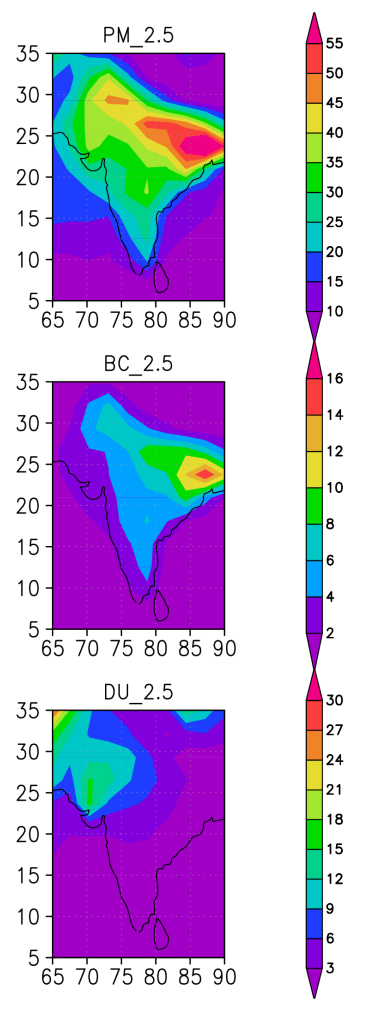

Fig. 2. Total surface $\mathrm{PM}_{2.5}$ in India and contributions to it from different aerosol species (four-year average (2006-2009), in units $\left.\mu \mathrm{g} \mathrm{m}^{-3}\right)$.

a negligible part of sulfate, black carbon and organic carbon mass concentration can be found in sizes $D>1 \mu \mathrm{m}$, we only plot the seasonal cycles of these aerosol species for a single size class, $\mathrm{PM}_{10.0}$. Spatial mass concentration distributions are shown for $\mathrm{PM}_{2.5}$, which was chosen because in this size class the maximum concentrations of anthropogenic and natural aerosols were closest to each other.

It is not self-evident how to distribute the AOD between the aerosol species. A simple diagnostic of splitting up the AOD according to volume fractions in the internally mixed particles is used. We split up the AOD of aerosol associated water to the hygroscopic species sulfate and sea salt based on concentrations and relative humidity according to the formula in (Jacobson et al., 1996). This simplified scheme is a choice among many possibilities, and though it underestimates the contribution of black carbon to AOD as the internally mixed assumption enhances absorption, its advantage lies in being simple and, in our opinion, accurate enough for the other species. A better estimate of absorption by black carbon can then be obtained from the absorption AOD.

Simulated AOD is compared to measurement results from MODIS, two AERONET stations and some stations measuring concentrations. We also compare our results to a modeling study by Adhikary et al. (2007), which consid-
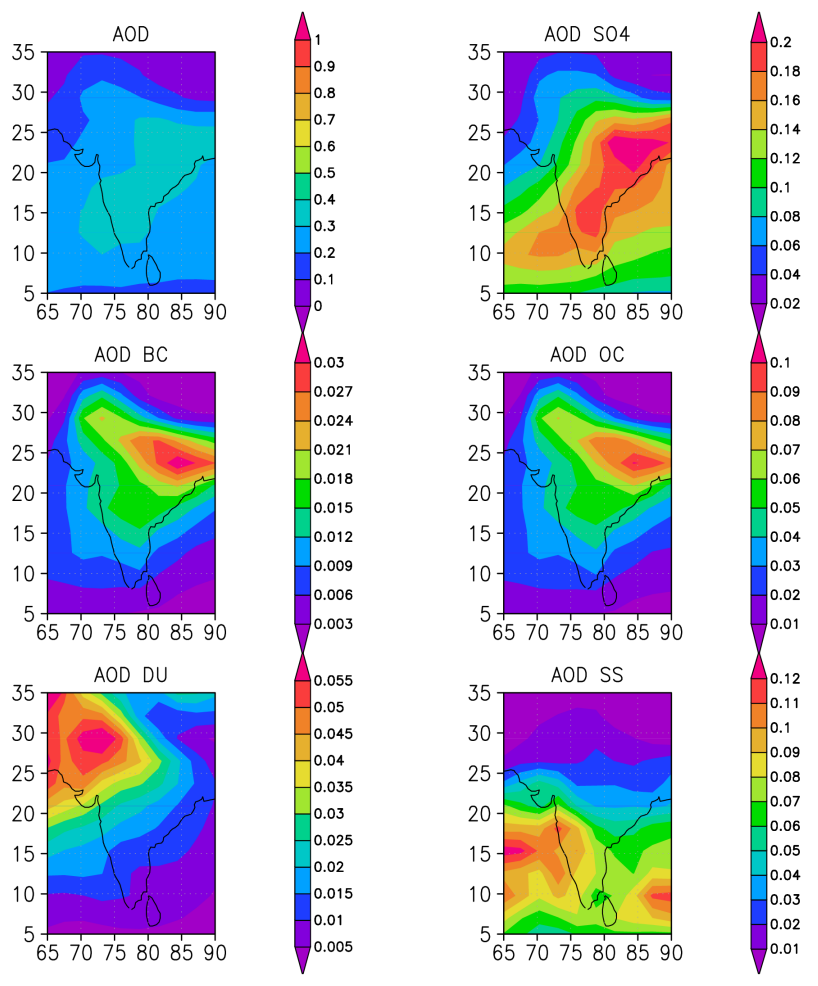

Fig. 3. Total AOD in India and contributions to it from different aerosol species (four-year average (2006-2009), unitless).

ers the time frame from September 2004 to August 2005 and to results of the GOCART chemical transport model for 2006. Different time frames occuring in the comparisons obviously create some discrepancy, but for the climatological aerosol properties studied here, the discrepancy is most probably small. In (Ramachandran and Cherian, 2008) it can be seen that the standard deviation of AOD monthly averages from the 5-yr mean taken between 2001-2005 is much smaller than the average value of AOD for all 20 locations in India considered in the study. We compare average AOD spatial distributions, seasonal cycles and interannual variability in India and China with data from the newer MODIS C5 dataset and AOD at two locations, Kanpur and Gandhi College, with AERONET data. The MODIS AODs presented consist of collection 4 data for years 20012005 over India (obtained from, Ramachandran and Cherian, 2008), for 2000-2005 over China (obtained from Kim et al., 2007), and collection 5 data for year 2006 over India and China (obtained from the GIOVANNI online data system, http://disc.sci.gsfc.nasa.gov/giovanni). The resolution of the MODIS data is $1^{\circ} \times 1^{\circ}$. The AERONET data is obtained from the AERONET homepage. 

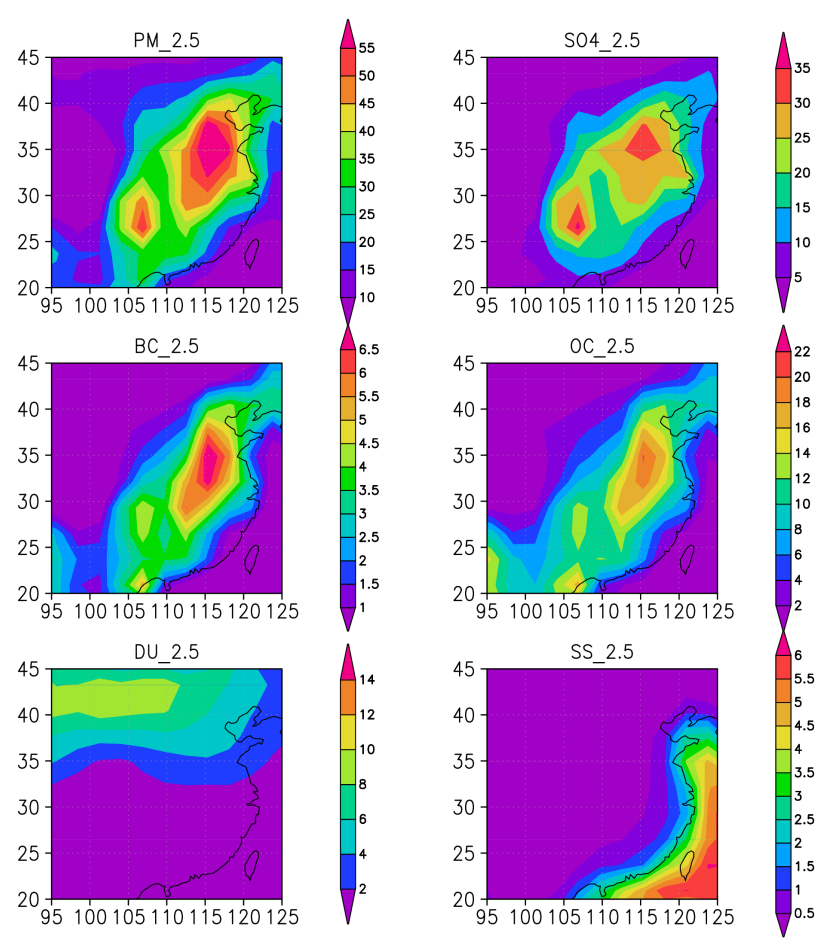

Fig. 4. Total surface $\mathrm{PM}_{2.5}$ in China and contributions to it from different aerosol species (four-year average (2006-2009), in units $\left.\mu \mathrm{g} \mathrm{m}^{-3}\right)$.

\subsection{Spatial distributions}

In India, the largest $\mathrm{PM}_{2.5}$ and $\mathrm{AOD}$ values occur in the Ganges basin and in the Kolkata region, with the annual grid box average $\mathrm{PM}_{2.5}$ value reaching $60 \mu \mathrm{g} \mathrm{m}^{-3}$ and AOD reaching values over 0.4 (Figs. 2 and 3). Sulfate, black carbon and organic carbon concentrations all peak in the same region, decreasing when going north or towards the sea. The largest mean sulfate, black carbon and organic carbon concentrations at this resolution are over $8 \mu \mathrm{g} \mathrm{m}^{-3}, 14 \mu \mathrm{g} \mathrm{m}^{-3}$ and $45 \mu \mathrm{g} \mathrm{m}^{-3}$, respectively (Fig. 2). Of the species emitted by anthropogenic sources, sulfate is distributed more widely than the carbonaceous species. Sulfate concentrations at sea far off the coast are often half of the concentrations in regions close to the sources while concentrations of black and organic carbon drop to a much smaller fraction of that in the source regions just outside the coast. The main reason for this difference is that most sulfur emissions are in the form of $\mathrm{SO}_{2}$ and therefore have a chance to get transported higher and longer than the carbon aerosols emitted as primary matter. It is well known that aerosol lifetime in the atmosphere is strongly dependent on emission height (see e.g. Balkanski, 1991). For this reason secondary organic aerosols (SOA) would probably also spread wider than primary particle emissions, if the SOA were not formed at the emission site as in the model. Dust concentrations peak in the Thar desert region in the west and in the north on the Tibetian plateau. Sea salt concentrations are highest above the sea, and higher over the Arabian sea than over the Bay of Bengal due to higher winds over the Arabian sea.

Our sulfate concentrations are similar to those in the modeling study by Adhikary et al. (2007), but black and organic carbon concentrations are higher. At least part of the explanation of this difference lies in the different emission inventories. The REAS inventory (Ohara et al., 2007) used in this study has black and organic carbon emissions over $50 \%$ higher than the inventory created by Streets et al. (2003) used in Adhikary et al. (2007). Above, we noted that in our simulations, the mass concentration of black and organic carbon decreases faster with increasing distance from source regions than the mass concentration of sulfate. In this respect, it is of interest to consider observational results for black and organic carbon. INDOEX results for the Kaashidoo Climate Observatory $\left(\mathrm{KCO}, 5^{\circ} \mathrm{N}, 73.5^{\circ} \mathrm{E}\right)$ in the Maldives southwest of the Indian peninsula showed that $\mathrm{PM}_{1}$ mass consisted of $32 \%$ sulfate, $26 \%$ organic carbon, $14 \%$ black carbon, $10 \%$ mineral dust, $1 \%$ sea salt and $13 \%$ ammonium and fly ash on average in February 1999 (Ramanathan et al., 2001). Corresponding values from our simulation, albeit from a different time frame, the four-year average concentrations in February 2006-2009 show $\mathrm{PM}_{1}$ consists of $45 \%$ sulfate, $34 \%$ organic carbon, $8 \%$ black carbon, $1 \%$ mineral dust and $10 \%$ sea salt. In February the winter monsoon winds blow from northeast transporting aerosols from India to KCO. In Moorthy et al. (2004), it was reported that during the intermonsoon season in March-April, the black carbon mass fraction was as low as $2.2 \%$ southwest of India in the Arabian Sea compared to $7-10 \%$ at the nearby coastal location of Trivandrum. During this time, the winds are weaker and therefore less capable to transport aerosols from sources on land. These results can be compared to the simulation results, again for a somewhat different time frame. Four-year average concentrations in March 2006-2009 show a 10.7\% black carbon mass fraction of $\mathrm{PM}_{2.5}$ in the grid point closest to Trivandrum $\left(5.9^{\circ} \mathrm{E}, 9.8^{\circ} \mathrm{N}\right)$ and a $4.4 \%$ black carbon mass fraction in the nearby gridpoint in the Arabian Sea $\left(73.1^{\circ} \mathrm{E}, 7.0^{\circ} \mathrm{N}\right)$. Also the measurements at the background station in Mukteshvar (northeast from Delhi) indicate 2-4\% mean mass fractions of black carbon in $\mathrm{PM}_{2.5}$ (Hyvärinen et al., 2009). Beegum et al. (2009) reported monthly mean black carbon concentrations measured at eight stations for January 2006 to May 2006 and found large variations within the country and between different months, with an average concentration of $0.065 \mu \mathrm{g} \mathrm{m}^{-3}$ over the Arabian sea in May and $27 \mu \mathrm{g} \mathrm{m}^{-3}$ in Delhi in January. Considering the results cited and presented in this paragraph, we find the differences in our spatial patterns of sulfate and carbonaceous aerosols qualitatively consistent with field measurements, which generally indicate smaller mass fractions of black carbon in remote regions.

In China, the largest $\mathrm{PM}_{2.5}$ mean values are found close to the east coast (Fig. 4). Yearly average $\mathrm{PM}_{2.5}$ values around Beijing exceed $55 \mathrm{\mu g} \mathrm{m}^{-3}$. Sulfate, black carbon and 

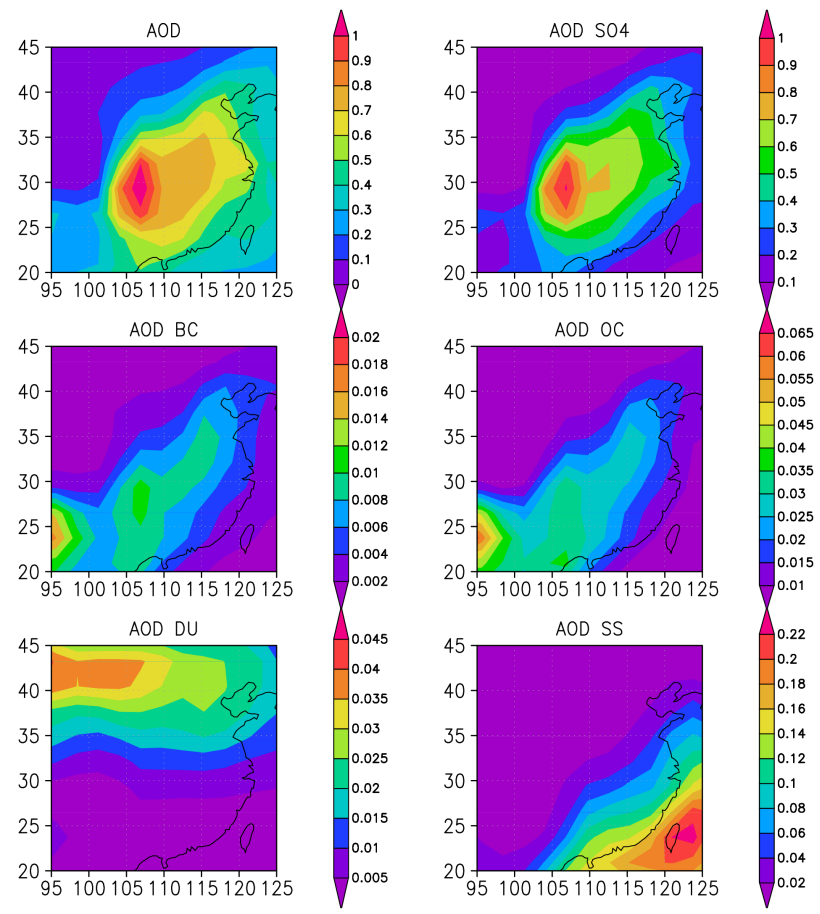

Fig. 5. Total AOD in China and contributions to it from different aerosol species (four-year average (2006-2009), unitless).

organic carbon concentrations exceed $35 \mu \mathrm{g} \mathrm{m}^{-3}, 6.5 \mu \mathrm{g} \mathrm{m} \mathrm{m}^{-3}$ and $20 \mu \mathrm{g} \mathrm{m}^{-3}$, respectively. The Sichuan basin located around $105^{\circ} \mathrm{E}, 30^{\circ} \mathrm{N}$ also has a local $\mathrm{PM}_{2.5}$ maximum and the largest local annual mean sulfate concentration and AOD can be found there (Fig. 5). The large positive difference between mean AOD in the Sichuan basin and the east coast is explained by higher relative humidity and hygroscopic growth of aerosols due to water condensing on sulfate. As in India, sulfate is more widely spread than black and organic carbon. Dust concentrations peak in the north near or outside the Mongolian border and sea salt concentrations peak over the sea.

In their study on MODIS Terra AOD data (coll. 4) for 2001-2005 in India, Ramachandran and Cherian (2008) found the smallest annual mean AOD of 0.28 in northeast India followed by 0.35 in southern India. The largest annual mean AOD 0.49 was found in eastern India followed by 0.47 in northern India. Our simulation results for the years 2006-2009 have the same qualitative features (Fig. 3), though the values are somewhat lower in the simulation. It should be noted, however, that at least over some urban locations in India the MODIS AODs (coll. 4) at $550 \mathrm{~nm}$ tend to be overestimated when compared to ground based AERONET measurements (Ramachandran, 2007). Over India, a similar AOD pattern for 2006 can be seen in the MODIS coll. 5 data (Fig. 6), though AOD values in the Ganges basin are higher, 0.5-0.7 and values in the Thar desert area are much higher

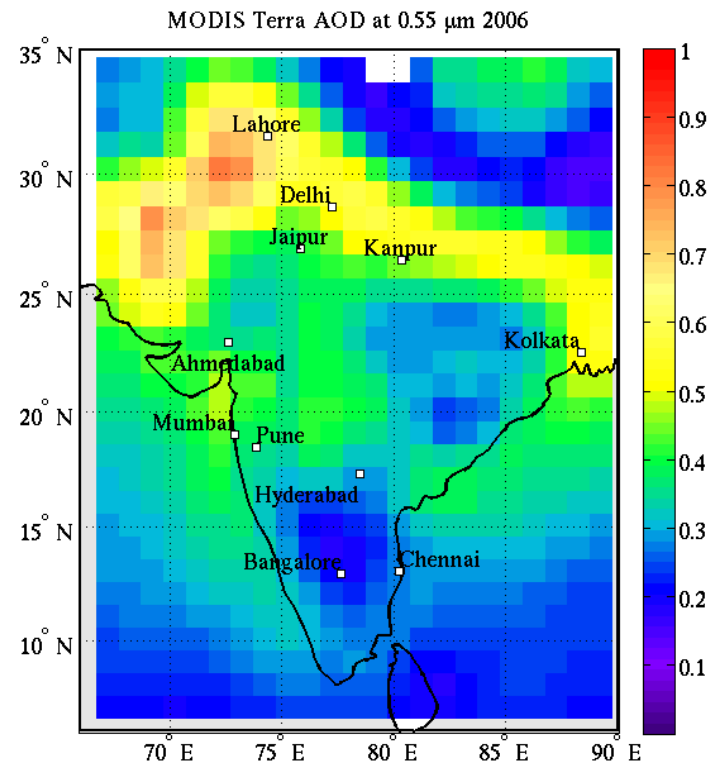

Fig. 6. AOD in India according to MODIS C5 data for 2006 (annual average, unitless).

than in the simulation. According to Levy et al. (2010) it is expected that the MODIS coll. 5 AODs are underestimated over semi-arid areas with high dust concentrations, hence the model underestimate in this region might be even larger than suggested by Fig. 6 .

Meng et al. (2007) reviewed aerosol concentrations from other measurements made in Beijing, Xi'an, Hong Kong and Koashung with measurements done between 1998 and 2006. The average black carbon concentrations in these urban areas were 4.0-9.7 $\mu \mathrm{g} \mathrm{m}^{-3}$ and the organic carbon concentrations $10.4-61.9 \mathrm{\mu g} \mathrm{m}^{-3}$, higher or roughly the same as our simulated grid box averages (Fig. 4). In their study on MODIS data averaged from April 2000 to June 2005, Kim et al. (2007) also found a local maximum at the Sichuan basin. Figure 7 shows the MODIS coll. 5 AODs over China in 2006. Here the AOD reaches the value 1.0 in the Sichuan basin. Our simulated AOD spatial pattern is qualitatively consistent with this MODIS-derived data, mean AOD being larger on the northern part of the east coast and on the south coast compared to the south-eastern coast. Values west of the Sichuan basin are very low both in the simulation and MODIS data. Our results have less local features, which is not surprising, since the MODIS data have a resolution of $1^{\circ} \times 1^{\circ} . \mathrm{PM}_{2.5}$ values in the Sichuan basin are lower than those on the northern east coast and the higher AOD is a result of hygroscopic growth of sulfate aerosols.

The GOCART chemical transport model results for 2006 (available at: http://disc.sci.gsfc.nasa.gov/giovanni, Aerosol Monthly, not shown here) show largest AOD values for India, 0.2-0.3, in the eastern part of the country and in most other parts the values are between 0.1 and 0.2. In China, the 


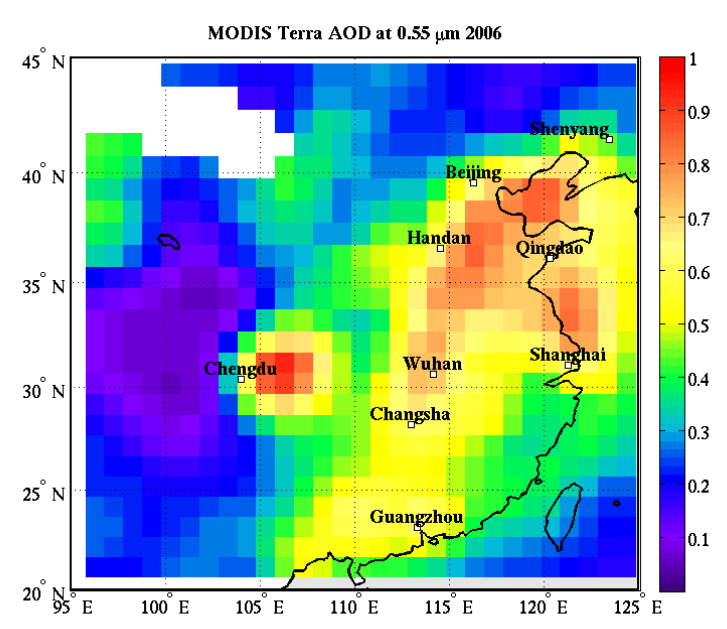

Fig. 7. AOD in China according to MODIS C5 data for 2006 (annual average, unitless).

GOCART results show a local maximum AOD of 0.6-0.7 in the Sichuan basin, another local maximum of 0.6-0.7 at $30^{\circ} \mathrm{N}, 115^{\circ} \mathrm{E}$, with values on the eastern and southeastern coast being 0.4-0.6. Thus, also the GOCART model shows much smaller values for the Ganges basin and Thar desert as compared to MODIS and for the rest of India there is some underestimate as well. The Sichuan basin maximum is also smaller than for MODIS, but for Eastern China the correspondence is good in general, with AOD values being somewhat smaller than in our simulation.

\subsection{Seasonal variations}

The annual cycle of $\mathrm{PM}_{2.5}$ and AOD in India consists of superimposed seasonal cycles of fine anthropogenic particles and coarse natural particles, with the seasonal cycle for anthropogenic aerosols (most of sulfate, BC and OC; see Sect. 5) having its maximum in the winter and that of natural aerosols having its maximum in the summer (Figs. 8-10). The overwhelming majority of sulfate, $\mathrm{BC}$ and $\mathrm{OC}$ particles lie in the $D<1 \mu \mathrm{m}$ regime and therefore we plot them only in one size class $\mathrm{PM}_{10}$. Mineral dust and sea salt distributions contain a lot of larger particles and therefore we also plot their contributions in the $\mathrm{PM}_{1}$ and $\mathrm{PM}_{2.5}$ classes separately (Fig. 9). From the PM figures it can be seen that the mass of natural aerosols, mineral dust and sea salt lies mainly in the $D>1 \mu \mathrm{m}$ regime. The seasonal cycles in India are strong, with monthly average concentrations of sulfate, black carbon and organic carbon varying by more than a factor of 2 and of mineral dust and sea salt by approximately a factor of 10 within the year. The strong maximum of anthropogenic aerosols in the winter is attributed mainly to lack of rain and wet removal of aerosols, and the strong maximum of natural aerosols in the summer is mainly attributed to high wind speed (see Fig. 12). Another important factor at work is the
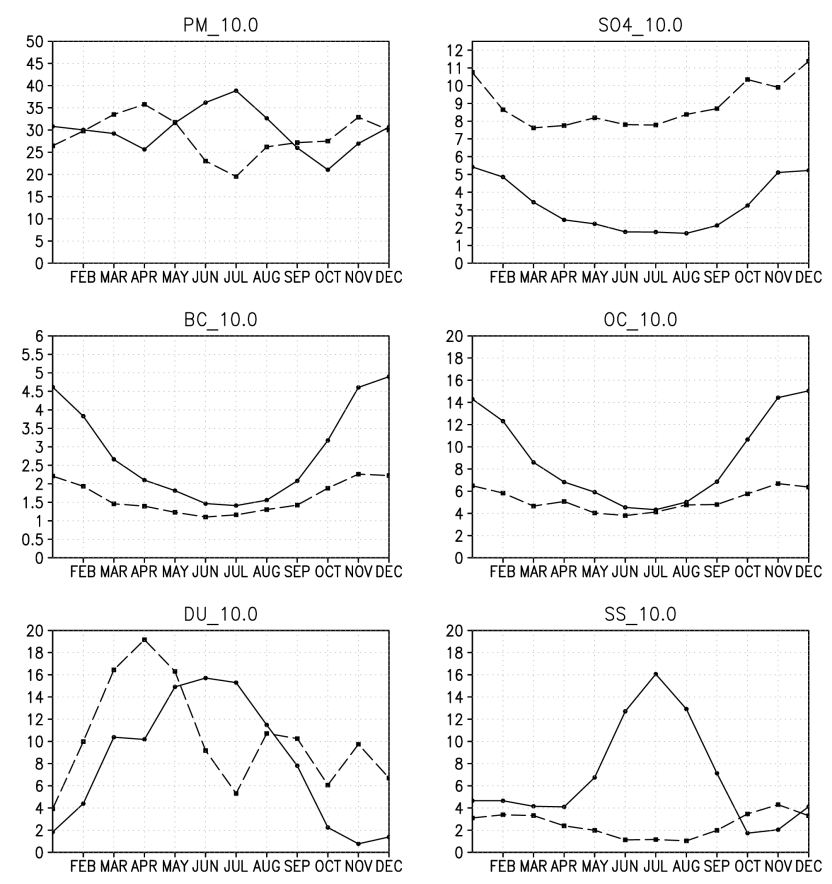

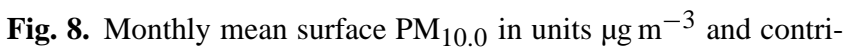
butions to it from different aerosol species for China (dashed line) and India (solid line), four-year average (2006-2009).
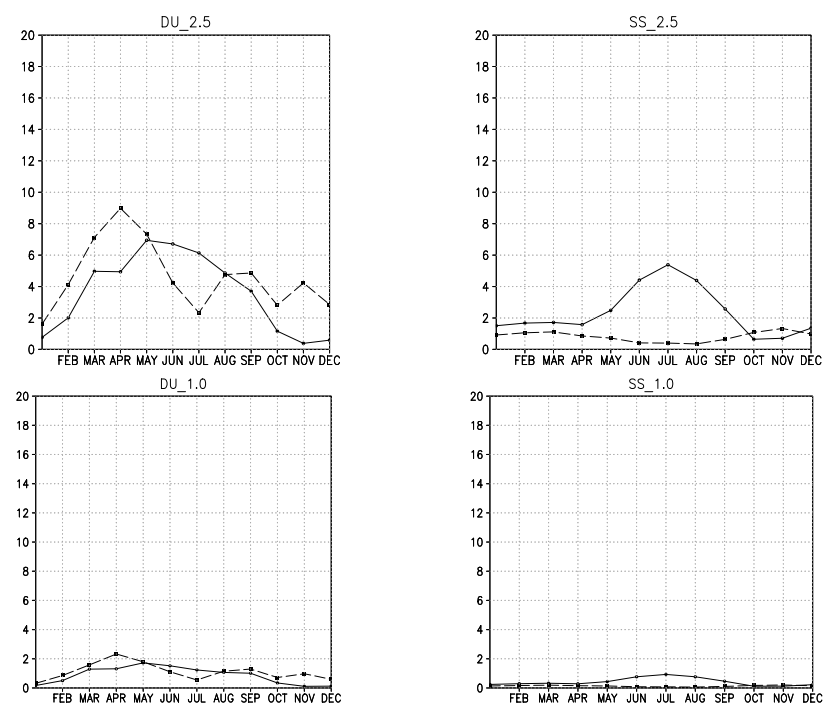

Fig. 9. Contributions of mineral dust and sea salt to the four-year mean surface mass concentration in size classes $\mathrm{PM}_{2.5}$ and $\mathrm{PM}_{1.0}$ for China (dashed line) and India (solid line), in units $\mu \mathrm{g} \mathrm{m}^{-3}$, fouryear average (2006-2009).

height of the boundary layer, which is lower in the winter and thereby causes higher surface concentrations. That the total columnar anthropogenic aerosol concentrations are indeed higher in the winter can be seen for instance in the AOD 

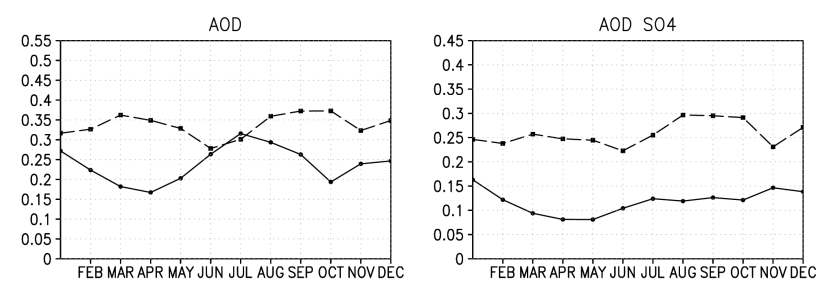

AOD BC
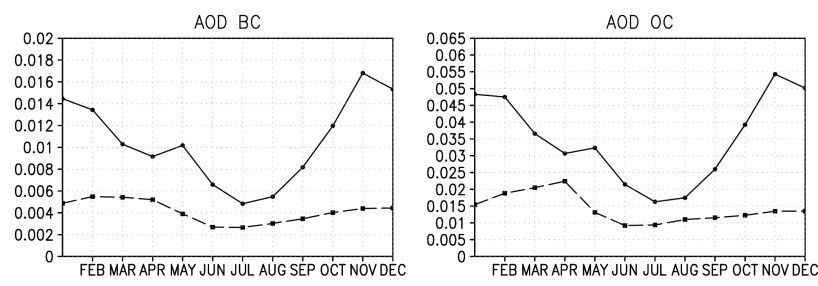

AOD DU
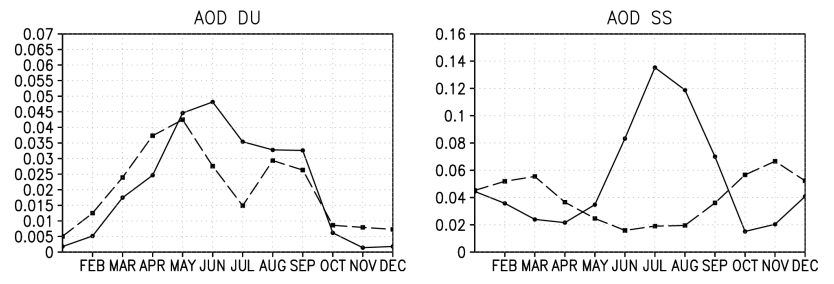

Fig. 10. Monthly mean AOD and contributions to it from different aerosol species for China (dashed line) and India (solid line), fouryear average (2006-2009).

values for the individual species (Fig. 10), which have similar seasonal cycles. The sulfate AOD seasonal cycle is weaker, indicating that removal of aerosols in the regions with high sulfate concentrations does not vary as much as elsewhere. If seasonality in anthropogenic emissions would be taken into account, the seasonal cycle of anthropogenic aerosol concentrations and AODs would be even stronger, because anthropogenic emissions are higher in the winter, as discussed in Sect. 3. The seasonal cycle can also be clearly seen in the absorption AOD monthly mean values, which vary from 0.015 in the summer to 0.037 in the winter, and in the Angstrom parameter monthly mean values, which vary from 0.8 in the summer to 1.6 in the winter (Fig. 11). The shape of the Indian-average AOD curve resembles well the majority of MODIS-derived curves for separate locations in (Ramachandran and Cherian, 2008), though our winter maximum seems to be relatively higher in comparison to the summer maximum. This might be due to the emissions in the year 2006 being higher than in years just before as Ramachandran and Cherian (2008) studied the period between 2001 and 2005 and because of an underestimated AOD in summer compared to MODIS, which will be shown later in this section.

In Adhikary et al. (2007)'s modeling study on southern Asia for the period September 2004 to August 2005, maxima for the anthropogenic aerosols species for most locations were seen in October-December, whereas our maximum is perhaps shifted forward by one month to NovemberJanuary. The average we obtain for India is consistent with
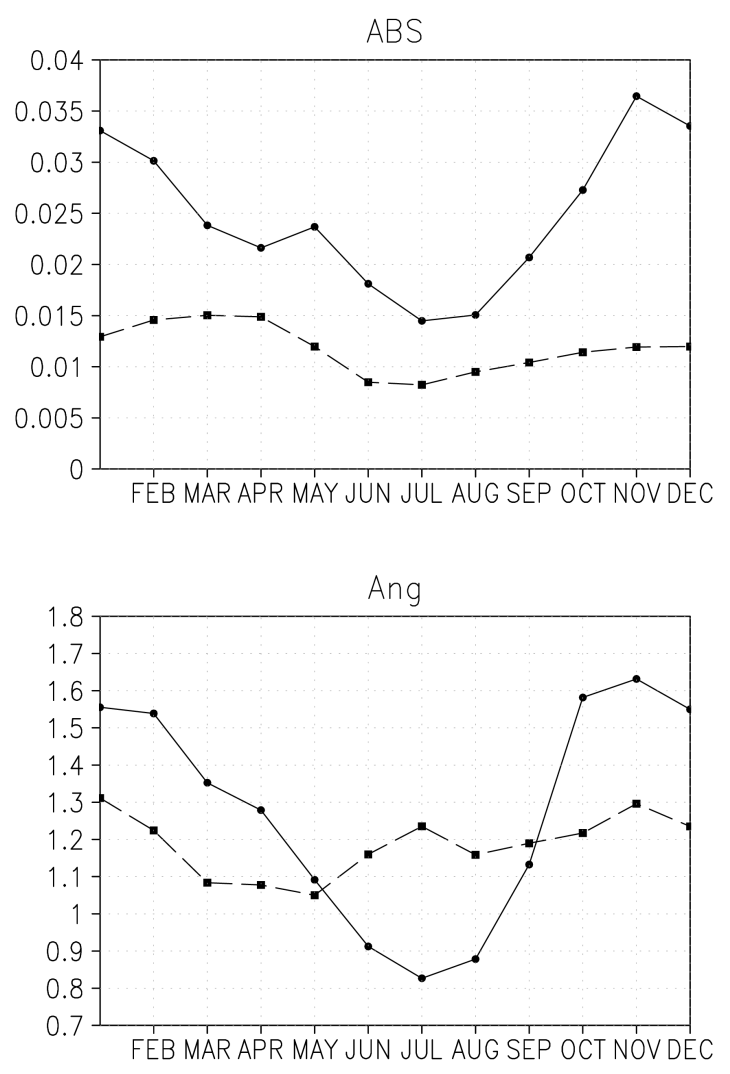

Fig. 11. Monthly mean (a) absorption AOD and (b) Angstrom parameter for China (dashed line) and India (solid line), four-year average (2006-2009).

this. As to natural aerosols, Adhikary et al. (2007) found a maximum in the summer, which is consistent with our results. AOD seasonal cycles from MODIS satellite measurements (Ramachandran and Cherian, 2008) and AERONET ground-based measurements (Singh et al., 2004) show summertime maxima mostly between May and August and secondary maxima in the winter between November and January. Our results are consistent with these measurements.

In China, the seasonal cycles are not quite as strong as in India (Figs. 8-11). Black carbon concentrations are higher in winter than in summer. The organic carbon concentration average is not changing as much and has a few smaller maxima. The average sulfate concentration is high in OctoberJanuary. AOD has maxima in February-May and in AugustOctober, with the first maximum explained more by natural aerosols and the second maximum explained more by sulfate.

Comparing the AOD seasonal cycle to the MODIS-derived result for data from April 2000 to June 2005 for a different averaging domain in Kim et al. (2007), the shapes of the AOD curves match well in the first half of the year with a spring maximum, but in the latter half of the year the simulation result has another maximum absent in the MODIS results. The high AOD in the latter half of the year might 


\section{R.H.}
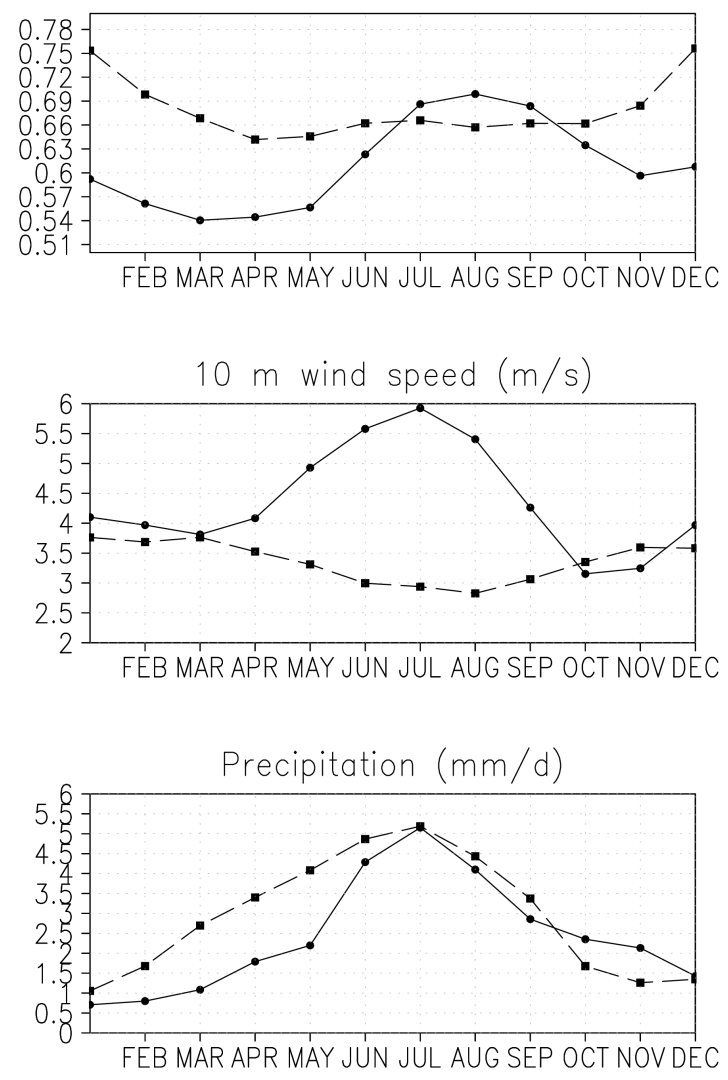

Fig. 12. Monthly mean RH, 10-m wind speed and precipitation for China (dashed line) and India (solid line), four-year average (20062009

be due to the fact that Chinese $\mathrm{SO}_{2}$ emissions were higher in 2006 than during the period from April 2000 to June 2005 . The large effect of the magnitude of Chinese $\mathrm{SO}_{2}$ emissions on AOD in the latter half of the year as well as emission trends are discussed in the article by Lu et al. (2010). Another possible partial explanation of high AODs in the latter half of the year is the recently found fact that ECHAM5-HAM overestimates $\mathrm{SO}_{2}$ concentrations in some regions (Kazil et al., 2010). In the next section it will be shown that reducing $\mathrm{SO}_{2}$ emissions and sulfate production affect the AOD more in the latter half of the year.

AOD seasonal cycles and interannual variability in India and China are compared to MODIS coll. 5 data from 20062009, averaged over the same domains, in Fig. 13. In India, the summer and winter maxima have the same timing both in the model and MODIS results, but the model seems to give a lower AOD throughout the year, with a large underestimate in spring and summer. As was discussed in the previous subsection, the Thar desert and Ganges basin areas with high dust and carbonaceous aerosol loads, respectively, show the largest differences. In China, the model gives a maximum in spring in the same months as MODIS, but with the MODIS
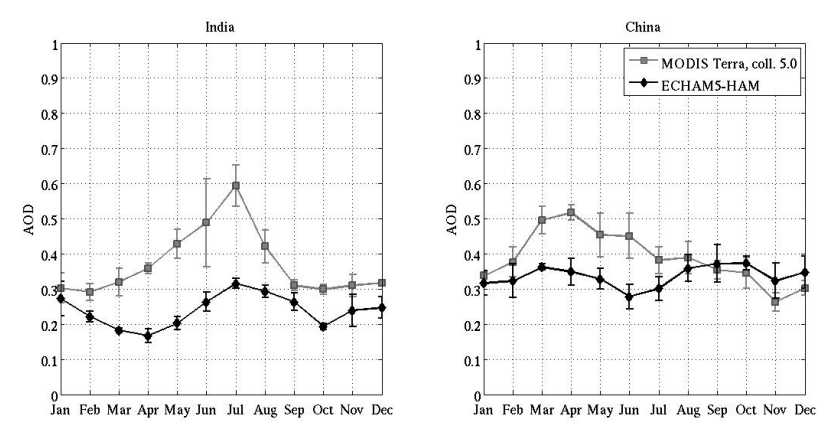

Fig. 13. Monthly mean AOD and interannual variability in MODIS data (gray) and the ECHAM5-HAM simulation (black) in India (left) and in China (right), solid line shows four-year average (20062009) and error bars show interannual variability as standard deviation.

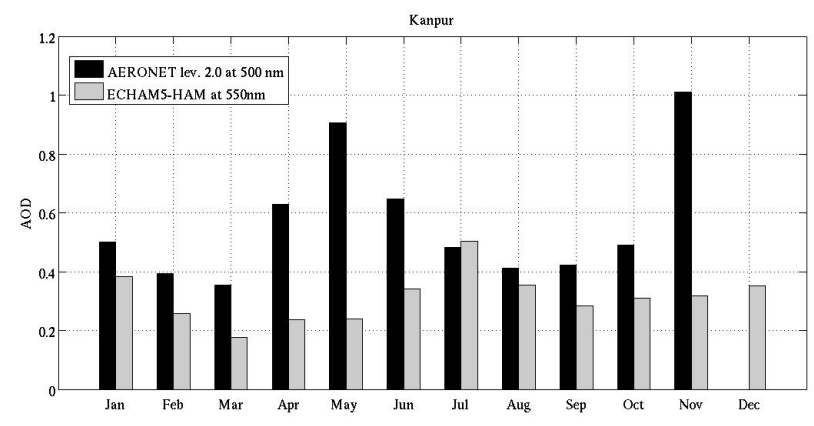

Fig. 14. AOD in Kanpur from AERONET point measurement in year 2006 at $\lambda=500 \mathrm{~nm}$ (black) and as a grid box four-year average from ECHAM5-HAM data using 2006 emissions at $\lambda=550 \mathrm{~nm}$ (grey).

AOD values being larger, about 0.5 compared to 0.35 . In the latter half of the year, the match is good with overlapping bars describing interannual variability. Thus, despite the larger Chinese $\mathrm{SO}_{2}$ emissions in the REAS inventory as compared to the estimates by Zhang et al. (2009) and Smith et al. (2011), the REAS 2006 prediction inventory gives a good match with the MODIS observations in the latter half of the year when the sulfate contribution is largest. Spring and summer in India and spring in China are the times of the year with the highest dust load, which could mean that dust AOD is underestimated in the model. It should also be kept in mind that, at least for some urban locations in India, MODIS AODs (coll. 4) at $550 \mathrm{~nm}$ tend to be overestimated when compared to ground based AERONET measurements (Ramachandran, 2007). Interannual variability seems to be larger for MODIS for May-August in India, but for other months interannual variability in MODIS and simulation results are about equal. In China, interannual variability seems to be about equal for the model and MODIS throughout the year. 


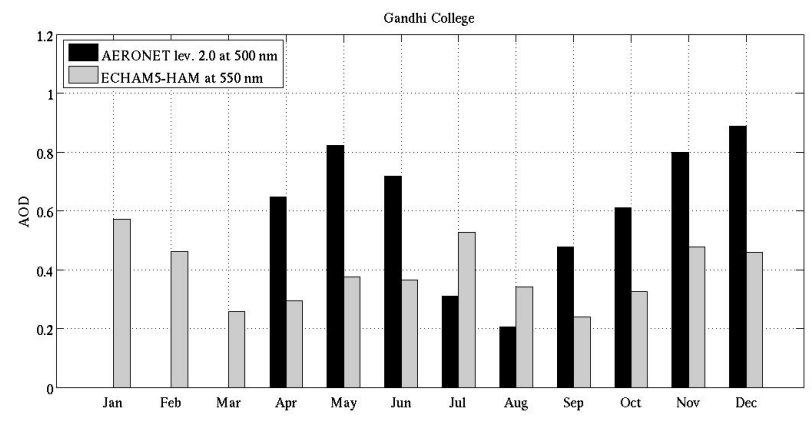

Fig. 15. AOD at Gandhi College from AERONET point measurement in year 2006 at $\lambda=500 \mathrm{~nm}$ (black) and as a grid box fouryear average from ECHAM5-HAM data using 2006 emissions at $\lambda=550 \mathrm{~nm}$ (grey).

Figures 14 and 15 show comparisons of simulation results with AERONET ground based data from 2006 for two locations in India: Kanpur $\left(26^{\circ} \mathrm{N}, 80^{\circ} \mathrm{E}\right)$ and Gandhi College $\left(25^{\circ} \mathrm{N}, 84^{\circ} \mathrm{E}\right)$. In Kanpur, the MODIS data shows a maximum in winter like in the simulation results, but the other maximum is in spring (April-June). In Gandhi College, the AERONET data also shows a maximum in spring. The modeling study by Adhikary et al. (2007) shows a maximum of fine-mode aerosols and particularly dust in April-May in Kanpur, which might indicate that ECHAM5-HAM gets the timing of the maximum in Kanpur slightly wrong. Also AERONET measurements analysed by Singh et al. (2004) indicate that dust loading in Kanpur has a maximum in April-May. Otherwise qualitative features are similar but AERONET AOD values mostly larger.

Comparison of simulated concentrations over India and China shows that sulfate concentrations are far larger in China than India with monthly means varying between 7 and $11 \mu \mathrm{g} \mathrm{m}^{-3}$ for China and between values less than $2 \mu \mathrm{g} \mathrm{m}^{-3}$ and just over $5 \mu \mathrm{g} \mathrm{m}^{-3}$ for India. This is due to the much higher $\mathrm{SO}_{2}$ emissions in China. The mean concentrations of black and organic carbon are higher in India than in China throughout the year, and the differences are much bigger in winter than in summer. In January the mean black carbon concentration is $4.6 \mu \mathrm{g} \mathrm{m}^{-3}$ in India and $2.2 \mu \mathrm{g} \mathrm{m}^{-3}$ in China and in July it is $1.5 \mu \mathrm{g} \mathrm{m}^{-3}$ in India and $1.2 \mu \mathrm{g} \mathrm{m}^{-3}$ in China. In total, China has slightly larger black carbon emissions than India, but the smaller area of India and especially the less efficient wet removal there in winter make the Indian black carbon concentrations higher. The largest dust concentrations are seen in March-May for China and in May-July in India, with highest monthly mean dust concentration in the $D<10 \mu \mathrm{m}$ size class being $16 \mu \mathrm{g} \mathrm{m}^{-3}$ in June for India and $19 \mu \mathrm{g} \mathrm{m}^{-3}$ in April for China. Sea salt concentrations are larger in India, but the values are not comparable because a larger fraction of the modelled Indian domain is covered with ocean than in the Chinese case.
Table 1. Percentage changes of anthropogenic emissions of different aerosol species in India and China. Change from REAS 2006 prediction inventory to each of the scenarios.

\begin{tabular}{lrrr}
\hline & REAS REF & $-2 \%$ per year & anthr. emiss. $=0$ \\
\hline $\mathrm{SO}_{2}$ India & +43.4 & -24.6 & -100 \\
$\mathrm{BC}$ India & +8.5 & -24.6 & -100 \\
$\mathrm{OC}_{\text {India }}$ & +8.4 & -24.6 & -100 \\
$\mathrm{SO}_{2}$ China & -22.3 & -24.6 & -100 \\
$\mathrm{BC}$ China & -38.8 & -24.6 & -100 \\
OC China & -39.4 & -24.6 & -100 \\
\hline
\end{tabular}

The four-year monthly mean $\mathrm{PM}_{2.5}$ in India has on average relative contributions of $15 \%$ sulfate, $13 \%$ black carbon, $43 \%$ organic carbon, $17 \%$ mineral dust and $12 \%$ sea salt. In China the relative contributions are $42 \%$ sulfate, $8 \%$ black carbon, $25 \%$ organic carbon, $22 \%$ mineral dust and $3 \%$ sea salt.

We wish to point out a few things that need to be considered when interpreting the results. Firstly, although the natural aerosols mineral dust and sea salt contribute significantly to the PM and AOD mean values, most of their contribution comes from regions with very low population density and low agricultural activity. Therefore the anthropogenic contribution to harmful pollution for human beings is larger than national averages would suggest. Secondly, most anthropogenic particles are in the size class $\mathrm{PM}_{1}$, but for the natural particles produced by action of the wind, less than $10 \%$ of the concentration comes from particles with $D<1 \mu \mathrm{m}$ and over $50 \%$ comes from particles with $D>2.5 \mu \mathrm{m}$. This suggests that $\mathrm{PM}_{1}$ and either $\mathrm{PM}_{10}$ or $\mathrm{PM}_{10-1}$ (i.e. concentration of particles with $1 \mu \mathrm{m}<D<10 \mu \mathrm{m}$ ) might be more optimal metrics of aerosol concentrations than $\mathrm{PM}_{2.5}$, a point that has been made also from a health impact perspective (Perez et al., 2009). Thirdly, the mean AOD is calculated for making comparisons between results from different sources, not for making deductions on radiative properties. The transmissivity of aerosols depend non-linearly on AOD and the radiative forcing yet on the strength of incoming solar radiation, the relation between scattering and absorption, and asymmetry in scattering.

\section{Results for future scenarios and without anthropogenic emissions}

In this section we will present results from a simulation with the REAS reference scenario for 2020 , from a simulation using the $-2 \%$ per year scenario for 2020 (with results for these two simulations being presented for 2020-2023) and from a simulation with no anthropogenic emissions for the years 2006-2009. We compare these results to the presentday simulation results presented in the previous section. In 

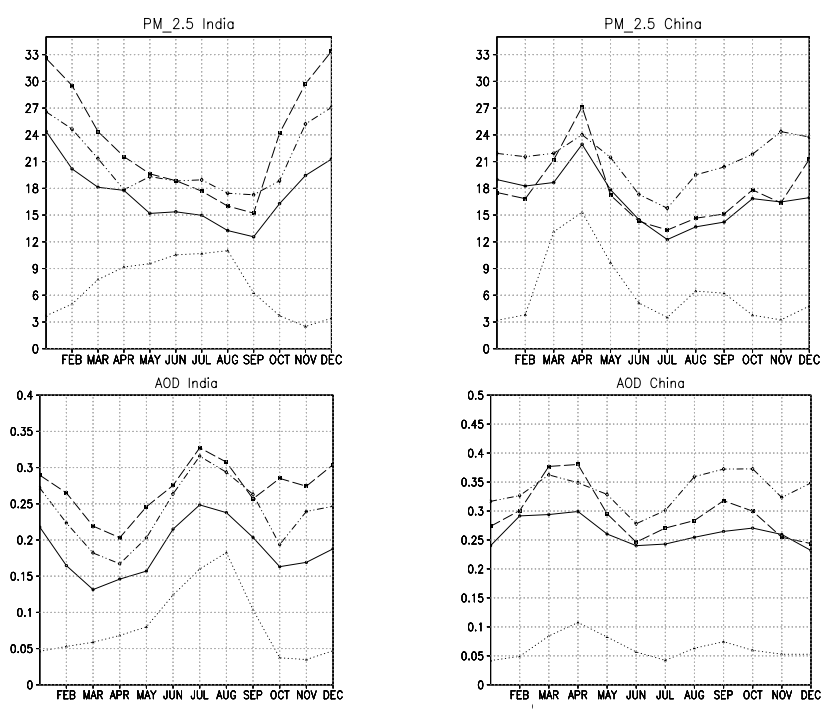

Fig. 16. Surface $\mathrm{PM}_{2.5}$ (in units $\mu \mathrm{g} \mathrm{m}^{-3}$ ) and AOD (unitless) for India and China in the cases: no anthropogenic emissions (dotted line), 2006 emissions (dot-dot-dashed line), REAS reference scenario for 2020 (dashed line) and the $-2 \%$ per year scenario (solid line), four-year average (2006-2009 for cases with no anthropogenic emissions and 2006 emissions and 2020-2023 for cases with REAS reference scenario and $-2 \%$ per year scenario emissions).

the REAS reference scenario, anthropogenic emissions of all aerosol species continue to increase in India, while in China they decrease. In the $-2 \%$ per year scenario anthropogenic sulfate, black carbon and organic carbon emissions decrease with a rate of 2 per cent per year from 2006 to 2020. Changes in anthropogenic emissions in India and China under the different scenarios are summarised in Table 1.

Simulation results for $\mathrm{PM}_{2.5}$ and $\mathrm{AOD}$ are shown in Fig. 16. Most of the sulfate, black carbon and organic carbon aerosols are of anthropogenic origin. In the simulation with no anthropogenic emissions, sulfate monthly mean concentrations are less than $0.5 \mu \mathrm{g} \mathrm{m}^{-3}$ for both India and China, organic carbon monthly mean concentrations are of the order $1 \mu \mathrm{g} \mathrm{m}^{-3}$ or less and black carbon monthly mean concentrations are less than $0.1 \mu \mathrm{g} \mathrm{m}^{-3}$ (see Tables 2 and 3). Monthly average $\mathrm{PM}_{2.5}$ values are still around $3-15 \mu \mathrm{g} \mathrm{m}^{-3}$ and AOD values around $0.04-0.18$ due to natural aerosols.

Relative changes of $\mathrm{PM}_{2.5}$ and AOD in the different scenarios are shown in Tables 2 and 3, separated by aerosol species. As expected, concentrations of an aerosol species and its AOD generally decrease when its emissions are decreased. In India, monthly sulfate concentrations are higher for all months in the REAS scenario. For black and organic carbon the nearly $10 \%$ increases compared to year 2006 cause the concentrations to rise mainly in OctoberFebruary while concentrations during the rest of the year are less affected (Fig. 16, concentrations of different species not
Table 2. Percentage changes of mass concentration and AOD of different aerosol species in India. Change from simulation of presentday Asia in the different scenarios.

\begin{tabular}{lrrr}
\hline & REAS REF & $-2 \%$ per year & anthr. emiss. $=0$ \\
\hline $\mathrm{PM}_{2.5}$ & +11.6 & -17.6 & -67.1 \\
$\mathrm{~S}_{4} 2.5$ & +43.2 & -22.5 & -87.1 \\
$\mathrm{BC} 2.5$ & +13.7 & -23.0 & -99.0 \\
OC2.5 & +12.5 & -21.2 & -90.8 \\
DU2.5 & -5.6 & -6.4 & -4.0 \\
SS2.5 & -11.6 & -7.5 & -6.8 \\
AOD & +13.6 & -21.7 & -65.2 \\
AOD_SO & +31.0 & -26.6 & -83.2 \\
AOD_BC & +7.0 & -27.3 & -97.8 \\
AOD_OC & +5.0 & -25.3 & -87.5 \\
AOD_DU & -17.3 & -14.9 & -2.0 \\
AOD_SS & -5.6 & -10.2 & -29.3 \\
\hline
\end{tabular}

shown). The AODs of the anthropogenic species increase. In China sulfate, black carbon and organic carbon mean concentrations decrease for all months in the REAS scenario compared to the present-day simulation (Fig. 16, concentrations of different species not shown). The AODs of the anthropogenic species also decrease.

In the $-2 \%$ per year scenario sulfate, black carbon and organic carbon monthly mean concentrations are all lower than in the present-day simulation except for the February mean sulfate concentration in China. The four-year mean $\mathrm{PM}_{2.5}$ value decreases by $17.6 \%$ in India and $20.6 \%$ in China. Mean sulfate, black carbon and organic carbon concentrations decrease by $22.5 \%, 23.0 \%$ and $21.2 \%$ in India and $25.8 \%, 25.8 \%$ and $22.5 \%$ in China, respectively. Mineral dust and sea salt concentrations vary less, as expected. Thus, in both India and China, the sulfate, black carbon and organic carbon concentrations experience a relative decrease approximately the same as the corresponding relative decrease in emissions. Changes in AOD for the different aerosol species are slightly but not much different from the changes in concentrations. Total AOD is affected both by changes in anthropogenic and natural emissions, with the latter depending on meteorological conditions, and therefore the total AOD does not necessarily decrease by the same amount as anthropogenic emissions. In this case the mean AOD decreases by $21.7 \%$ in India and by $22.0 \%$ in China.

We can compare the AOD seasonal cycles of China and India in these future simulations (Fig. 16) to the MODISderived seasonal cycles (Fig. 13). The AOD curve for India in the $-2 \%$ per year and REAS reference scenario simulations resemble, like in the case with REAS 2006 emissions, the MODIS-derive curve. The underestimate is slightly smaller in the REAS reference scenario simulation, especially in the winter, which could mean that anthropogenic 
Table 3. Percentage changes of mass concentration and AOD of different aerosol species in China. Change from simulation of presentday Asia in the different scenarios.

\begin{tabular}{lrrr}
\hline & REAS REF & $-2 \%$ per year & anthr. emiss. $=0$ \\
\hline PM $_{2.5}$ & -16.2 & -20.6 & -69.2 \\
$\mathrm{SO}_{4} 2.5$ & -20.6 & -25.8 & -96.7 \\
$\mathrm{BC} 2.5$ & -33.9 & -25.8 & -98.3 \\
OC2.5 & -29.1 & -22.5 & -85.2 \\
DU2.5 & +9.2 & -10.4 & +1.0 \\
SS2.5 & -5.6 & +1.3 & +6.0 \\
AOD & -12.3 & -22.0 & -81.0 \\
AOD_SO 4 & -14.7 & -24.7 & -93.3 \\
AOD_BC & -16.0 & -25.7 & -94.7 \\
AOD_OC & -12.4 & -20.9 & -76.6 \\
AOD_DU & +7.2 & -11.7 & +2.8 \\
AOD_SS & -5.7 & -6.4 & -4.7 \\
\hline
\end{tabular}

emissions in India are underestimated in the REAS 2006 prediction inventory. The AOD curve for China using REAS emissions gives the best fit to MODIS data from 2006-2009, suggesting that especially anthropogenic $\mathrm{SO}_{2}$ emissions are at least not much overestimated in the REAS inventory.

\section{Conclusions}

We have presented results for aerosol seasonal cycles and spatial distributions in India and China seen in a global climate-aerosol model using the Regional Asian Emission Inventory. The modelled aerosol species were sulfate, black carbon, organic carbon, mineral dust and sea salt. Sulfate, black carbon and organic carbon particles were found mostly in the $D<1 \mu \mathrm{m}$ regime, whereas the natural particles typically had diameters larger than $1 \mu \mathrm{m}$ and a large part of their mass in size classes larger than $\mathrm{PM}_{2.5}$. The Indian and Chinese aerosol characteristics and seasonal cycles differed from each other. India had higher concentrations of black and organic carbon and China had higher concentrations of sulfate. The Indian aerosol seasonal cycle consisted of a strong natural cycle with a maximum in the spring-summer (MayJuly) and a strong anthropogenic cycle having a maximum in the winter (November-January). The seasonal cycle of natural aerosols was quite strong in China too with a maximum in spring (March-May), but the seasonal cycle of anthropogenic aerosols was not as strong with area-mean quantities varying less from month to month.

An interesting feature in the simulations is the difference between spatial patterns of sulfate and carbonaceous aerosols, sulfate concentrations remaining high far away from sources and black and organic carbon concentrations decreasing faster with distance. We attribute this to the fact that $\mathrm{SO}_{2}$ can be transported higher and further away from the sources before being converted to particles compared to carbonaceous aerosols that are emitted in particulate form. Another interesting feature was the high AOD in the Sichuan basin in China caused mainly by high sulfate concentrations combined with high relative humidity.

Our present-day simulation reproduced MODIS-derived AOD seasonal cycles reasonably well for India and China. Of course the absolute value of AOD should not be used as a single metric for air quality since the same AOD can be caused by a number of different aerosol distributions. In India, monthly average AOD is largest when fine anthropogenic particle pollution is at its lowest.

We performed future simulations for 2020 using two scenarios: the REAS reference scenario and a $-2 \%$ per year scenario. In general, concentrations in the future simulations had the same trends as emissions. Cuts in anthropogenic emissions also influenced the seasonal cycles, mainly because of different relative contributions of anthropogenic and natural aerosols at different times of the year. In India mostly wintertime concentrations and AOD were effected and in China emission cuts affected the AOD most during the latter half of the year. However, emission cuts led to lower $\mathrm{PM}_{2.5}$ and AOD during the entire year in both countries.

In summary, we have presented an analysis illustrating the contributions of anthropogenic and natural aerosols to different aerosol size classes and aerosol optical depth at large scale in India and China and how changes in anthropogenic emissions influence the concentrations, AOD and their seasonal cycles.

Acknowledgements. Financial support by the Ministry for Foreign Affairs of Finland, and the Academy of Finland (project numbers 129355 and 133142 , and the project number 118615 of the National Centre of Excellence in Research Programme) is gratefully acknowledged.

REAS inventory is owned by Frontier Research Center for Global Change (FRCGC), Japan Agency for Marine-Earth Science and Technology (JAMSTEC). The REAS work was supported by the Global Environment Research Fund(B-051) of the Ministry of the Environment, Ministry of Education, Culture, Sports, Science and Technology (MEXT), Japan and RR2002 of MEXT, Japan.

The MODIS coll. 5 data were produced with the Giovanni online data system, developed and maintained by the NASA GES DISC. The AERONET data were downloaded from the AERONET homepage: http://aeronet.gsfc.nasa.gov/.

Edited by: M. Kulmala 


\section{References}

Adhikary, B., Carmichael, G. R., Tang, Y., Leung, L. R., Qian, Y., Schauer, J. J., Stone, E. A., Ramanathan, V., and Ramana, M. V..: Characterization of the seasonal cycle of south Asian aerosols: A regional-scale modeling analysis, J. Geophys. Res., 112, D22S22, doi:10.1029/2006JD008143, 2007.

Adhikary, B., Kulkarni, S., Dallura, A., Tang, Y., Chai, T., Leung, L. R., Qian, Y., Chung, C. E., Ramanathan, V., and Carmichael, G. R.: A regional scale chemical transport modeling of Asian aerosols with data assimilation of AOD observations using optimal interpolation technique, Atmos. Environ., 42, 8600-8615, 2008.

Andres, R. J. and Kasgnoc, A. D.: A time-averaged inventory of subaerial volcanic sulfur emissions, J. Geophys. Res., 103, 25251-25261, 1998.

Balkanski, Y. J.: Atmospheric residence times of continental aerosols, Ph.D. thesis, Harvard University, 1991.

Beegum, G. N., Moorthy, K. K., Babu, S. S., Sathhesh, S., Vinoj, V., Badarinath, K., Safai, P., Devara, P., Singh, S., Vinod, Dumka, U., and Pant, P.: Spatial distribution of aerosol black carbon over India during pre-monsoon season, Atmos. Environ., 42, 10711078, 2009

Bruce, N., Perez-Padilla, R., and Albalak, R.: The health effects of indoor air pollution exposure in developing countries, World Health Organization, Geneve, 2002.

Carmichael, G. C., Adhikary, B., Kulkarn, S., D’Allura, A., Tang, Y., Streets, D., Zhang, Q., Bond, T. C., Ramanathan, V., Jamroensa, A., and Marrapu, P.: Asian Aerosols: Current and Year 2030 Distributions and Implications to Human Health and Regional Climate Change, Environ. Sci. Technol., 43, 5811-5817, 2009

Carrico, M. C., Bergin M. H., Shrestha A. B., Dibb, J. E., Gomes L., and Harris, J. M.: The importance of carbon and mineral dust to seasonal aerosol properties in the Nepal Himalaya, Atmos. Environ., 37, 2811-2824, 2003.

Chung, C. E. and Ramanathan, V.: Weakening of Northern Indian SST gradients and the monsoon rainfall in India and the Sahel, J. Climate, 19, 2036-2045, 2006.

Edwards, R. D., Liu, Y., He, G., Yin, Z., Sinton, J., Peabody, J., and Smith, K. R.: Household CO and PM measured as part of a review of China's National Improved Stove Program, Indoor Air 17, 189-203, 2007.

Franke, K., Ansmann, A., Müller, D., Althausen, D., Venkataraman, C., Reddy, M. S., Wagner, F., and Scheele, R.: Optical properties of the Indo-Asian haze layer over the tropical Indian Ocean, J. Geophys. Res., 108, 4059, doi:10.1029/2002JD002473, 2003.

GEIA/ACCENT Emissions: REAS Inventory for Asia, available at: http://www.aero.jussieu.fr/projet/ACCENT/REAS.php, 2008.

Guenther, A., Hewitt, C. N., Erickson, D., Fall, R., Geron, C., Graedel, T., Harley, P., Klinger, L., Lerdau, M., McKay, W. A., Pierce, T., Scholes, B., Steinbrecher, R., Tallamraju, R., Taylor, J., and Zimmerman, P.: A global model of natural volatile organic compound emissions, J. Geophys. Res., 100, 8873-8892, 1995.

Halmer, M. M., Schmincke, H.-U., and Graf, H.-F.: The annual volcanic gas input into the atmosphere, in particular into the stratosphere: a global data set for the past 100 years, Journal of Volcanology and Geothermal Research, 115, 511-528, 2002.

Hanbar, R. D. and Karve, P.: National Programme on Improved
Chulha (NPIC) of the Government of India: an overview, Energy for Sustainable Development, 6, 49-55, 2002.

Hyvärinen, A.-P., Lihavainen, H., Komppula, M., Sharma, V. P., Kerminen, V.-M., Panwar, T. S., and Viisanen, Y.: Continuous measurements of optical properties of atmospheric aerosols in Mukteshvar, Northern India, J. Geophys. Res., 114, D08207, doi:10.1029/2008JD011489, 2009.

Hyvärinen, A.-P., Lihavainen, H., Komppula, M., Panwar, T. S., Sharma, V. P., Hooda, R. K., and Viisanen, Y.: Aerosol measurements at the Gual Pahari EUCAARI station: preliminary results from in-situ measurements, Atmos. Chem. Phys., 10, 72417252, doi:10.5194/acp-10-7241-2010, 2010.

Jacob, D. J., Crawford, J. H., Kleb, M. M., Connors, V. S., Bendura, R. J., Raper, J. L., Sachse, G. W., Gille, J. C., Emmons, L., and Heald, C. L.: Transport and Chemical Evolution over the Pacific (TRACE-P) aircraft mission: Design, execution, and first results, J. Geophys. Res., 108(D20), 9000, doi:10.1029/2002JD003276, 2002.

Jacobson, M. Z., Tabazadeh, A., and Turco, R. P.: Simulating equilibrium within aerosols and nonequilibrium between gases and aerosols, J. Geophys. Res., 101(D4), 9079-9091, 1996.

Kazil, J., Stier, P., Zhang, K., Quaas, J., Kinne, S., O’Donnell, D., Rast, S., Esch, M., Ferrachat, S., Lohmann, U., and Feichter, J.: Aerosol nucleation and its role for clouds and Earth's radiative forcing in the aerosol-climate model ECHAM5-HAM, Atmos. Chem. Phys., 10, 10733-10752, doi:10.5194/acp-1010733-2010, 2010.

Kehrwald, N. M., Thompson, L. G., Tandong, Y., MosleyThompson E., Schotterer, U., Alfimov, V., Beer, J., Eikenberg, J., and Davis, M. E.: Mass loss on Himalayan glacier endangers water resources, Geophys. Res. Lett., 35, L22503, doi:10.1029/2008GL035556, 2008

Kettle, A. and Andreae, M.: Flux of the dimethylsulfide from the oceans: A comparison of updated data sets and flux models, J. Geophys. Res., 105, 26793-26808, 2000.

Kim, S.-W., Yoon, S.-C., Kim, J., and Kim, S.-Y.: Seasonal and monthly variations of columnar aerosol optical properties over east Asia determined from multi-year MODIS, LIDAR and AERONET Sun/sky radiometer measurements, Atmos. Environ., 41, 1634-1651, 2007.

Klimont, Z., Cofala, J., Xing, J., Wei, W., Zhang, C., Wang, S., Kejun, J., Bhandari, P., Mathur, R., Purohit, P., Rafaj, P., Chambers, A., Amann, M., and Hao, J.: Projections of $\mathrm{SO}_{2}, \mathrm{NO}_{\mathrm{x}}$ and carbonaceous aerosols emissions in Asia, Tellus, 61B, 602-617, 2009.

Komppula, M., Lihavainen, H., Hyvärinen, A.-P., Kerminen, V.-M., Panwar, T. S., Sharma, V. P., and Viisanen, Y.: Physical properties of aerosol particles at a Himalayan background site in India, J. Geophys. Res., 114, D12202, doi:10.1029/2008JD011007, 2009.

Levy, R. C., Remer, L. A., Kleidman, R. G., Mattoo, S., Ichoku, C., Kahn, R., and Eck, T. F.: Global evaluation of the Collection 5 MODIS dark-target aerosol products over land, Atmos. Chem. Phys., 10, 10399-10420, doi:10.5194/acp-10-10399-2010, 2010.

Lu, Z., Streets, D. G., Zhang, Q., Wang, S., Carmichael, G. R., Cheng, Y. F., Wei, C., Chin, M., Diehl, T., and Tan, Q.: Sulfur dioxide emissions in China and sulfur trends in East Asia since 2000, Atmos. Chem. Phys., 10, 6311-6331, doi:10.5194/acp-106311-2010, 2010. 
Marsland, S. J., Haak, H., Jungclaus, J. H., Latif, M., and Roske, F.: The Max-Planck-Institute global ocean/sea ice model with orthogonal curvilinear coordinates, Ocean. Model., 5, 91-127, 2003.

Meng, Z. Y., Jiang, X. M., Yan, P., Lin, W. L., Zhang, H. D., and Wang, S. F.: Characteristics and sources of $\mathrm{PM}_{2.5}$ and carbonaceous species during winter in Taiyuan, China, Atmos. Environ., 41, 6901-6908, 2007.

Moorthy, K. K., Babu, S. S., and Satheesh, S. K.: Aerosol characteristics and radiative impacts over the Arabian Sea during the intermonsoon season: Results from ARMEX field campaign, J. Atmos. Sci., 62, 192-206, 2004.

Mönkkönen, P., Uma, R., Srinivasan, D., Koponen, I. K., Lehtinen, K.E.J., Suresh, R., Sharma, V. P., and Kulmala, M.: Relationship and variations of aerosol number and PM10 mass concentrations in a highly polluted urban environment New Delhi, India, Atmos. Environ., 36, 425-433, 2004

Mönkkönen, P., Koponen, I. K., Lehtinen, K. E. J., Hämeri, K., Uma, R., and Kulmala, M.: Measurements in a highly polluted Asian mega city: observations of aerosol number size distribution, modal parameters and nucleation events, Atmos. Chem. Phys., 5, 57-66, doi:10.5194/acp-5-57-2005, 2005.

Müller, D., Tesche, M., Eichler, H., Engelmann, R., Althausen, D., Ansmann, A., Cheng; Y. F., Zhang, Y., and Hu, M.: Strong particle absorption over the Pearl River Delta (south China) and Beijing (north China) determined from combined Raman lidar and Sun photometer observations, Geophys. Res. Lett., 33, GL027196, doi:10.1029/2006GL027196, 2006.

Nakicenovic, N., Alcamo, J., Davis, G., de Vries, B., Fenhann, J., Gaffin, S., Gregory K., A. Grübler, Jung, T. Y., Kram, T., Lebre La Rovere, E., Michaelis, L., Mori, S., Morita, T., Pepper, W., Pitcher, H., Price, L., Riahi, K., Roehrl, A., Rogner, H.-H., Sankovski, A., Schlesinger, M., Shukla, P., Smith, S., Swart, R., van Rooijen, S., Victor, N., and Dadi, Z.: IPCC special report on emission scenarios. Cambridge University Press, Cambridge, 599 pp., 2000.

Nightingale, P., Malin, G., Law, C., Watson, A., Liss, P., Liddicoat, M., Boutin, J., and Upstill-Goddard, R.: In situ evaluation of airsea gas exchange parameterizations using novel conservative and volatile tracers, Global Biogeochem. Cy., 14, 373-387, 2000.

Ohara, T., Akimoto, H., Kurokawa, J., Horii, N., Yamaji, K., Yan, X., and Hayasaka, T.: An Asian emission inventory of anthropogenic emission sources for the period 1980-2020, Atmos. Chem. Phys., 7, 4419-4444, doi:10.5194/acp-7-4419-2007, 2007.

Pham, M., Muller, J.-F., Brasseur, G., Granier, C., and Megie, G.: A three-dimensional study of the tropospheric sulfur cycle, J. Geophys. Res. 100, 26061-26092, 1995.

Perez, L., Medina-Ramón, M., Künzli, N., Alastuey, A., Pey, J., Pérez, N., Garcia., R., Tobias, A., Querol, X., and Sunyer, J.: Size Fractionate Particulate Matter, Vehicle Traffic, and CaseSpecific Daily Mortality in Barcelona, Spain, Environ. Sci. Technol., 1(43), 4707-4714 doi:10.1021/es8031488, 2009.

Ramachandran, S.: Aerosol optical depth and fine mode fraction variations deduced from Moderate Resolution Imaging Spectroradiometer (MODIS) over four urban areas in India, J. Geophys. Res. 112, D16207, doi:10.1029/2007JD008500, 2007.

Ramachandran, S. and Cherian, R.: Regional and seasonal variations in aerosol optical characteristics and their frequency dis- tributions over India during 2001-2005, J. Geophys. Res., 113, D08207, doi:10.1029/2007JD008560, 2008.

Ramanathan, V.: New Directions: Atmospheric Brown Clouds, Atmos. Environ., 37, 4033-4035, 2003.

Ramanathan, V. and Carmichael, G.: Global and regional climate changes due to black carbon, Nature Geosci., 1, 221-227, 2008.

Ramanathan, V. and Feng, Y.: Air pollution, greenhouse gases and climate change: Global and regional perspectives, Atmos. Environ., 43, 37-50, 2009.

Ramanathan, V., Crutzen, P. J., Lelieveld, J., Mitra, A. P., Althausen, D., Anderson, J., Andreae, M. O., Cantrell, W., Cass, G. R., Chung, C. E., Clarke, A. D., Coakley, J. A., Collins, W. D., Conant, W. C., Dulac, F., Heintzenberg, J., Heymsfield, A. J., Holben, B., Howell, S., Hudson, J., Jayaraman, A., Kiehl, J. T., Krishnamurti, T. N., Lubin, D., McFarquhar, G., Novakov, T., Ogren, J. A., Podgorny, I. A., Prather, K., Priestley, K., Prospero, J. M., Quinn, P. K., Rajeev, K., Rasch, P., Rupert, S., Sadourny, R., Satheesh, S. K., Shaw, G. E., Sheridan, P., and Valero, F. P. J.: Indian Ocean Experiment: An integrated analysis of the climate forcing and effects of the great Indo-Asian haze, J. Geophys. Res., 106, 28371-28398, 2001.

Ramanathan, V., Li, F., Ramana, M. V., Praveen, P. S., Kim, D., Corrigan, C. E., Nguyen, H., Stone, E. A., Schauer, J. J., Carmichael, G. R., Adhikary, B., and Yoon, S. C.: Atmospheric brown clouds: Hemispherical and regional variations in long-range transport, absorption and radiative forcing, J. Geophys. Res., 112, D22S2, doi:10.1029/2006JD008124, 2007.

Ramanathan, V. M., Agrawal, M., Akimoto, H., Aufhammer, M., Devotta, S., Emberson, L., Hasnain, S. I., Iyngararasan, M., Jayaraman, A., Lawrance, M., Nakajima, T., Oki, T., Rodhe, H., Ruchirawat, M., Tan, S. K., Vincent, J., Wang, J. Y., Yang, D., Zhang, Y. H., Autrup, H., Barregard, L., Bonasoni, P., Brauer, M., Brunekreef, B., Carmichael, G., Chung, C. E., Dahe, J., Feng, Y., Fuzzi, S., Gordon, T., Gosain, A. K., Htun, N., Kim, J., Mourato, S., Naeher, L., Navasumrit, P., Ostro, B., Panwar, T., Rahman, M. R., Ramana, M. V., Rupakheti, M., Settachan, D., Singh, A. K., St. Helen, G., Tan, P. V., Viet, P., Yinlong, J., Yoon, S. C., Chang, W.-C., Wang, X., Zelikoff, J., and Zhu, A.: Atmospheric Brown Clouds: Regional Assessment Report with Focus on Asia, UNEP, Nairobi, 2008.

Roeckner, E., Baeuuml, G., Bonaventura, L., Brokopf, R., Esch, M., Giorgetta, M., Hagemann, S., Kirchner, I., Kornblueh, L., Manzini, E., Rhodin, A., Schlese, U., Schulzweida, U., and Tompkins, A.: The atmospheric general circulation model ECHAM5. Part I: Model description, Report 349, Max Planck Institute for Meteorology, Hamburg, Germany, available at http: //www.mpimet.mpg.de, 2003.

Roeckner, E., Brokopf, R., Esch, M., Giorgetta, M., Hagemann, S., Kornblueh, L., Manzini, E., Schlese, U., and Schulzweida, U.: Sensitivity of Simulated Climate to Horizontal and Vertical Resolution in the ECHAM5 Atmosphere Model, J. Clim., 19, 3771-3791, 2006a.

Roeckner, E., Stier, P., Feichter, J., Kloster, S., Esch, M., and Fischer-Bruns, I.: Impact of carbonaceous aerosol emissions on regional climate change, Clim. Dynam., 27, 553-571, 2006b.

Schulz, M., de Leeuw, G., and Balkanski, Y.: Emission Of Atmospheric Trace Compounds, chap. Sea-salt aerosol source functions and emissions, 333-359, Ed. Kluwer, 2004.

Seinfeld, J. H., Carmichael, G. R., Arimoto, R., Conant, W. C., 
Brechtel, F. J., Bates, T. S., Cahill, T. A., Clarke, A. D., Doherty, S. J., Flatau, P. J., Huebert, B. J., Kim, J., Markowicz, K. M., Quinn, P. K., Russell, L. M., Russell, P. B., Shimizu, A., Shinozuka, Y., Song, C. H.., Youhua, T., Itsushi, U., Vogelmann, A. M., Weber, R. J., Woo, J.-H., and Zhang, X. Y.: ACE.-ASIA Regional climatic and atmospheric chemical effects of asian dust and pollution, B. Am. Meteor. Soc., 85, 367-380, 2004.

Singh, R. P., Dey, S., Tripathi, S. N., and Tare, V.: Variability of aerosol parameters over Kanpur, northern India, J. Geophys. Res., 109, D23206, doi:10.1029/2004JD004966, 2004.

Smith, S. J., van Aardenne, J., Klimont, Z., Andres, R. J., Volke, A., and Delgado Arias, S.: Anthropogenic sulfur dioxide emissions: 1850-2005, Atmos. Chem. Phys., 11, 1101-1116, doi:10.5194/acp-11-1101-2011, 2011.

Stier, P., Feichter, J., Kinne, S., Kloster, S., Vignati, E., Wilson, J., Ganzeveld, L., Tegen, I., Werner, M., Balkanski, Y., Schulz, M., Boucher, O., Minikin, A., and Petzold, A.: The aerosolclimate model ECHAM5-HAM, Atmos. Chem. Phys., 5, 11251156, doi:10.5194/acp-5-1125-2005, 2005.

Streets, D. G, Bond, T. C., Carmichael, G. R., Fernandes, S. D., Fu, Q., He, D., Klimont, Z., Nelson, S. M., Tsai, N. Y., Wang, M. Q., Woo, J.-H., and Yarber, K. F.: An inventory of gaseous and primary aerosol emissions in Asia in the year 2000, J. Geophys. Res., 109, D24212, doi:10.1029/2002JD003093, 2003.

Tegen, I., Harrison, S. P., Kohfeld, K., Prentice, I. C., Coe, M., and Heimann, M.: Impact of vegetation and preferential source areas on global dust aerosol: Results from a model study, J. Geophys. Res., 107, 4576-4597, 2002. van der Werf, G. R., Randerson, J. T., Collatz, G. J., and Giglio, L.: Carbon emissions from fires in tropical and subtropical ecosystems, Glob. Change Biol., 9, 547-562, 2003.

Venkataraman, C., Habib, G., Kadamba, D., Shrivastava, M., Leon, J.-F., Crouzille, B., Boucher, O., and Streets, D. G: Emissions from open biomass burning in India: Integrating the inventory approach with highresolution Moderate Resolution Imaging Spectroradiometer (MODIS) activefire and land cover data, Global Biogeochem. Cy., 20, GB2013, doi:10.1029/2005GB002547, 2006.

Vignati, E., Wilson, J., and Stier, P.: M7: An efficient size-resolved aerosol microphysics module for large-scale aerosol transport models, J. Geophys. Res., 109, D22202, doi:10.1029/2003JD004485, 2004.

Xin, H. and Stone, R.: Q\&A: China's Scientist Premier, Science, 322, 362-364, 2008.

$\mathrm{Xu}, \mathrm{Q}$.: Abrupt change of the mid-summer climate in central East China by the influence of atmospheric pollution, Atmos. Environ., 35, 5029-5040, 2001.

Zhang, Q., Streets, D. G., Carmichael, G. R., He, K. B., Huo, H., Kannari, A., Klimont, Z., Park, I. S., Reddy, S., Fu, J. S., Chen, D., Duan, L., Lei, Y., Wang, L. T., and Yao, Z. L.: Asian emissions in 2006 for the NASA INTEX-B mission, Atmos. Chem. Phys., 9, 5131-5153, doi:10.5194/acp-9-5131-2009, 2009. 